\title{
Thallium (Tl) sorption onto illite and smectite: Implications for Tl mobility in the environment
}

\author{
Loïc A. Martin $^{\mathrm{a}, *}$, Aubéry Wissocq ${ }^{\mathrm{b}}$, M.F. Benedetti ${ }^{\mathrm{a}}$, Christelle Latrille $^{\mathrm{b}}$ \\ a Institut de Physique du Globe de Paris - USPC - UMRCNRS7154, Paris, France \\ ben-Service d'étude du Comportement des Radionucléides (SECR), CEA, Université Paris-Saclay, F91191 Gif-sur-Yvette, France
}

Received 19 October 2017; accepted in revised form 13 March 2018; available online 21 March 2018

\begin{abstract}
Clay minerals play a relevant role in the transport and fate of trace elements in the environment. Though illite has been referred as an important Thallium (Tl) bearing phase in soils, mechanisms and affinity of thallium for clay minerals remain poorly known. This study investigated the sorption behavior of thallium as Tl(I) onto illite and smectite, two clay minerals occurring mainly in soils and sediments. Different sorption experiments were carried out under various $\mathrm{pH}$ conditions and $\mathrm{Tl}$ concentrations, in competition with sodium and calcium at a constant ionic strength of $0.01 \mathrm{~mol} \mathrm{~L}^{-1}$. Our results showed that illite displayed more affinity than smectite for thallium. With illite, the distribution coefficients $\left(K_{\mathrm{d}}\right.$ in $\left.\mathrm{L} \mathrm{kg}^{-1}\right) \mathrm{varied}$ between $10^{2.75 \pm 0.17}$ and $10^{4.0 \pm 0.17}$ in Na solutions versus between $10^{2.25 \pm 0.17}$ and $10^{3.0 \pm 0.17}$ in Ca solutions, depending on pH. With smectite, $K_{\mathrm{d}}\left(\mathrm{in} \mathrm{L} \mathrm{kg}^{-1}\right.$ ) ranged between $10^{2.50 \pm 0.16}$ and $10^{3.20 \pm 0.16}$ and between $10^{1.25 \pm 0.16}$ and $10^{1.95 \pm 0.16}$ in $\mathrm{Na}$ and $\mathrm{Ca}$ solutions, respectively. Sorption behavior was described with the Multi-Site Ion Exchanger model and selectivity coefficients with respect to protons were calculated for the first time. In all cases, independently of clay mineral and background electrolyte, low capacity but highly reactive sites were dominant in thallium uptake, highlighting Tl affinity for those sites. Moreover, the exchangeable and reversible interactions between $\mathrm{Tl}^{+}$and clays reactive sites suggested that in changing conditions, thallium could be released in solution. The role of clay minerals in thallium environmental cycle is evident and confirmed illite to be a dominant $\mathrm{Tl}$ bearing phase, in some environment competing with manganese oxides. Compared to others $\mathrm{Tl}$ bearing mineral phases, clays are ranked as follows: $\mathrm{MnO}_{2}>$ illite $>$ smectite $\sim$ ferrihydrite $\geq \mathrm{Al}_{2} \mathrm{O}_{3} \sim$ goethite $>$ SiO . Finally, over the three monovalent cations ( $\mathrm{Tl}, \mathrm{Rb}, \mathrm{Cs}) \mathrm{Tl}$ is the one less sorbed on illite independently of the background cations.
\end{abstract}

(C) 2018 Elsevier Ltd. All rights reserved.

Keywords: Thallium; Smectite; Illite; Multi-Site ion Exchanger model

\section{INTRODUCTION}

Thallium ( $\mathrm{Tl})$ is a heavy metal which can be highly toxic for mammals mainly due to the similar behavior of $\mathrm{Tl}^{+}$ compared to $\mathrm{K}^{+}$in biological processes (RodríguezMercado and Altamirano-Lozano, 2013). It is recognized

\footnotetext{
* Corresponding author at: CAT/WATER/ERIN/LIST, 41 rue du Brill, 4422 Belvaux, Luxembourg.

E-mail addresses: loic.martin@list.lu (L.A. Martin), aubery. wissocq@sfr.fr (A. Wissocq), benedetti@ipgp.fr (M.F. Benedetti), christelle.latrille@cea.fr (C. Latrille).
}

to be as toxic as lead, cadmium, mercury or arsenic (Rodríguez-Mercado and Altamirano-Lozano, 2013).

Thallium is a widely distributed trace element on earth with an average concentration of $0.49 \mathrm{ppm}$ in the continental crust and $0.13 \mathrm{ppm}$ in the oceanic crust (Peter and Viraraghavan, 2005). It occurs in two oxidation states, T1 (I) and Tl(III) (Vink, 1993; Kaplan and Mattigod, 1998) with $\mathrm{Tl}(\mathrm{I})$ the only species issued from the mantle to the non-altered crust (Prytulak et al., 2017). Tl(I) is the most dominant and thermodynamically stable species in the sub-surface environment (Vink, 1993; Xiong, 2009; Casiot et al., 2011). However, in some environments, $\mathrm{Tl}(\mathrm{III})$ is 
detected in various amounts (Lin and Nriagu, 1999; Peacock and Moon, 2012; Voegelin et al., 2015; Campanella et al., 2017). Thallium(I) exhibits both chalcophile and lithophile behavior (McGoldrick et al., 1979; Baker et al., 2010; Biagioni et al., 2013; Hettmann et al., 2014; Prytulak et al., 2017). It has a large ionic radius (1.50 $\AA$, 6-fold coordination), similar to $\mathrm{K}^{+}, \mathrm{Rb}^{+}$and $\mathrm{Cs}^{+}$ (Shannon, 1976). Classically, Tl is assumed to substitute $\mathrm{K}^{+}$in biotite, $\mathrm{K}$-feldspar in volcanic rocks and granitic systems (Prytulak et al., 2017).

Thallium has two main sources in sub-surface environments. The first one corresponds to the weathering of $\mathrm{K}$ rich rocks (Vaněk et al., 2009) and/or S-rich minerals and more rarely Tl-rich sulfides deposit (Kaplan and Mattigod, 1998; Xiao et al., 2004; Voegelin et al., 2015) and the second one corresponds to anthropogenic sources. Contaminations result from mining of ferrous and nonferrous sulfide ores (Lis et al., 2003; Casiot et al., 2011; Karbowska, 2016; Campanella et al., 2017), from smelting activities, coal combustion and cement production (Cheam, 2001; Lis et al., 2003; Vaněk et al., 2013; Karbowska, 2016) as well as effluents of industry which use thallium compounds (Bennett, 2017).

Nielsen et al. (2005) reported an average concentration of thallium of $3.00 \pm 2.64 .10^{-11} \mathrm{~mol} \mathrm{~L}^{-1}$ for sixteen rivers worldwide. However, in highly contaminated area, in particular in acid mine drainage, concentration can reach $\sim 1.0 \cdot 10^{-6} \mathrm{~mol} \mathrm{~L}^{-1}$ (Casiot et al., 2011). In nonanthropogenic impacted soils formed from Tl-bearing bedrocks, Tl contents are widespread, varying from around 1.5 ppm (Vaněk et al., 2009) to 6000 ppm (Voegelin et al., 2015). Those ranges largely depend on the geological background. Conversely, in anthropogenically impacted soils without Tl-bearing bedrocks, $\mathrm{Tl}$ concentrations range between 5 ppm and 124 ppm (Lis et al., 2003; Xiao et al., 2004; Vaněk et al., 2013).

The dominant aqueous species of thallium (I) is $\mathrm{Tl}^{+}$ (Vink, 1993; Kaplan and Mattigod, 1998; Xiong, 2007; Casiot et al., 2011). Indeed, thallium (I) makes few complexes with anions, such as sulfate, carbonate and phosphate (Kaplan and Mattigod, 1998; Casiot et al., 2011), except with $\mathrm{Cl}^{-}$in seawater (Kaplan and Mattigod, 1998). Therefore, Tl remains mostly as a free and bioavailable ion in solution (Vink, 1993; Jacobson et al., 2005a; Casiot et al., 2011; Voegelin et al., 2015). However, in the particulate and colloidal fractions in waters, in sediments or in soils, thallium interacts with various phases. Thallium has strong affinity for manganese oxides (Bidoglio et al., 1993; Jacobson et al., 2005a; Liu et al., 2011; Peacock and Moon, 2012; Voegelin et al., 2015) and Mn(IV)oxides, such as birnessite, are known to oxidize $\mathrm{Tl}(\mathrm{I})$ in $\mathrm{Tl}$ (III) (Peacock and Moon, 2012; Voegelin et al., 2015). Iron oxy-hydroxides (Liu et al., 2011; Casiot et al., 2011; Coup and Swedlund, 2015) have medium/low affinity for thallium. They are mostly known to weakly sorb $\mathrm{Tl}(\mathrm{I})$ (Liu et al., 2011; Casiot et al., 2011; Coup and Swedlund, 2015) although iron reduction with UV might oxidize T1 (I) and stabilize the resulting Tl(III) (Karlsson et al., 2006).

Shaw (1952) and Prytulak et al. (2017) stipulate that $\mathrm{Tl}^{+}$ might substitute $\mathrm{K}^{+}$in secondary minerals during their for- mation processes, due to its lithophile behavior and a similar ionic radius. Besides, Jacobson et al. (2005a) and Voegelin et al. (2015) highlighted the role of Tl uptake by clay minerals in soils. Nevertheless, it was pointed out that processes and affinity of thallium for clays remain poorly known and further studies are needed (Voegelin et al., 2015). As for other trace elements, chemical adsorption on clay minerals is recognized to play a relevant role on their mobility in the environment. Consequently, in this study we have chosen to examine thallium sorption onto two major clay minerals, illite and smectite, present in soils and river sediments. The purpose has been, (1) to assess the clay mineral exchange properties that drive the $\mathrm{Tl}$ uptake on those surfaces and, (2) to evidence the affinity of $\mathrm{Tl}$ for these minerals. In order to be close to environmental conditions, $\mathrm{Ca}$ and $\mathrm{Na}$ were chosen as competing cations towards thallium for batch experiments. Then, sorption and its reversibility were tested over a large $\mathrm{pH}$ range and $\mathrm{Tl}$ concentrations. A thermodynamic multi-site ion exchange model is used to interpret the experimental data, and (3) to discuss the relative role played by clay minerals in thallium environmental cycle in the sub-surface environment.

\section{EXPERIMENTAL}

\subsection{Thallium species and isotopes in batch solutions}

As mentioned in introduction, $\mathrm{Tl}(\mathrm{I})$ dominates thallium speciation in the environment (Vink, 1993; Kaplan and Mattigod, 1998). Fig. 1 shows Tl speciation in aqueous systems containing $10 \mathrm{mM} \mathrm{CaCl}_{2}$ (Fig. $1 \mathrm{~A}$ and $\mathrm{B}$ ) or $10 \mathrm{mM}$ $\mathrm{NaCl}$ (Fig. 1C and D), similar conditions to our batch experiments. At low $\mathrm{pH}$ and high $\mathrm{Eh}, \mathrm{Tl}^{3+}$ is stable under aqueous $\mathrm{TlCl}_{3}$ (in $\mathrm{NaCl}$ ) or $\mathrm{TlCl}_{4}^{-}$(in $\mathrm{CaCl}_{2}$ ). At high $\mathrm{pH}, \mathrm{Tl}^{+}$is hydrolyzed $(\mathrm{TlOH})$ as is $\mathrm{Tl}^{3+}$ at higher Eh values forming $\mathrm{TlOH}_{3}$ and $\mathrm{TlOH}_{4}^{-}$aqueous complexes (Fig. 1). Thallium concentrations seem to have no effect on its speciation in those cases (Fig. 1A, B, C and D). During experiments ( $\mathrm{pH} 3-11)$, redox potentials (Eh in V) were measured with a Pt electrode (Metrohm) on random samples. Average value (at $\mathrm{T}=20.1^{\circ} \mathrm{C}$ ) was $195.7 \pm 4.3 \mathrm{mV}(\mathrm{n}=3)$. This condition placed in $\mathrm{Tl}$ diagrams (Fig. 1) confirms that $\mathrm{Tl}(\mathrm{I})$ would be the only stable form of thallium during batch experiments. Moreover, $\mathrm{Tl}$ species distribution in these specific condition (Eh, $\mathrm{pH}$ and $\mathrm{Tl}$ concentrations), reveals that $\mathrm{Tl}^{+}$represents more than $95 \%$ of $\mathrm{Tl}(\mathrm{I})$ species in our experiments (SI, Fig. S1).

Radioactive and stable $\mathrm{Tl}$ solutions were used in this study. Tl occurs in the environment only with two stable isotopes, ${ }^{203} \mathrm{Tl}(29.5 \%)$ and ${ }^{205} \mathrm{Tl}(70.5 \%)$ (Rehkämper and Nielsen, 2004). The radioisotope ${ }^{204} \mathrm{Tl}$, used here as radiotracer, does not exist naturally but only after neutron activation of stable thallium. Its half-life is 3.78 years. Therefore, a ${ }^{204} \mathrm{Tl}$ solution of $4.90 \mathrm{MBq}$ in $1 \mathrm{M} \mathrm{HCl}$ (Eckert \& Ziegler ${ }^{\circledR}$, source \# 1876-98, 07/01/16; initial Tl concentration of $2.80 \cdot 10^{-7} \mathrm{~mol} \mathrm{~L}^{-1}$ ) was used. Two daughter solutions were made with $1 \mathrm{~mL}$ of parent solution diluted in $10 \mathrm{~mL}$ of ultrapure water (milli Q $18.2 \mathrm{M} \Omega \mathrm{cm}^{-2}$, Millipore $^{\circledR}$ ). They were composed of $\sim 0.1 \mathrm{M} \mathrm{HCl}$ (dilution fac- 

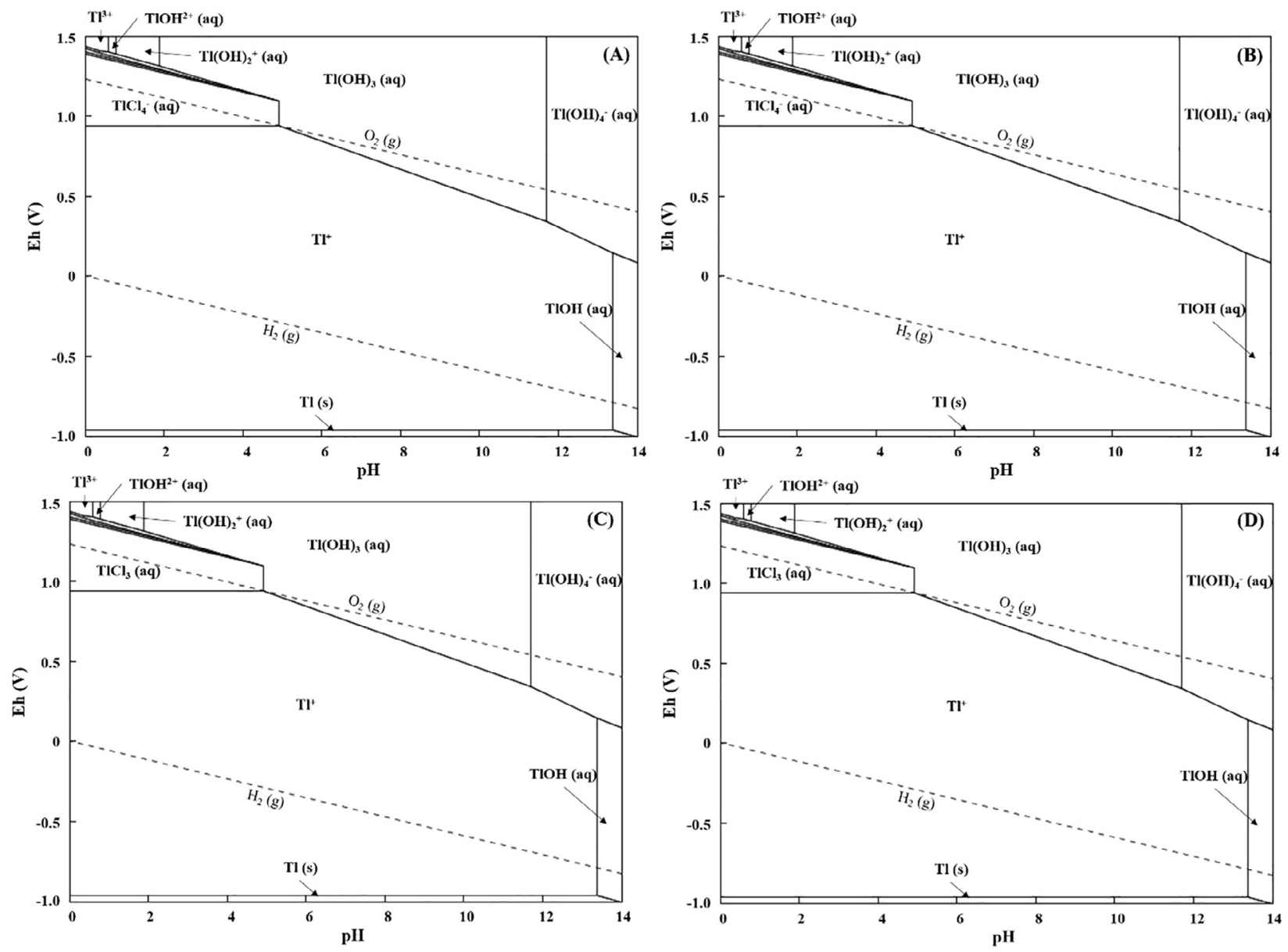

Fig. 1. Eh-pH diagrams for thallium. A Tl-Ca-Cl- $\mathrm{H}_{2} \mathrm{O}$ system is described for $\mathrm{A}$ and $\mathrm{B}$ with $\left[\mathrm{CaCl}_{2}\right]=10 \mathrm{mM}$. In $\mathrm{A}$, $[\mathrm{Tl}]=100 \mathrm{nM}$ and in $\mathrm{B}$, $[\mathrm{Tl}]=0.1 \mathrm{nM}$. C and D describe a Tl-Na-Cl- $\mathrm{H}_{2} \mathrm{O}$ system with $[\mathrm{NaCl}]=10 \mathrm{mM}$ and $[\mathrm{Tl}]=100 \mathrm{nM}$ for C and $0.1 \mathrm{nM}$ for D. Tl constants database is from Casiot et al. (2011) except for TlOH(aq) which is calculated from Brown and Ekberg's book (2016). Diagrams made with JChess v2.0.

tor of 9.80 for solution 1 and 9.92 for solution 2) for an initial activity of $1.01 \mathrm{MBq}\left([\mathrm{Tl}]=3.19 \cdot 10^{-8} \mathrm{~mol} \mathrm{~L}^{-1}\right)$ and $0.99 \mathrm{MBq}\left([\mathrm{Tl}]=3.14 \cdot 10^{-8} \mathrm{~mol} \mathrm{~L}{ }^{-1}\right)$, respectively. The solution of stable thallium was made by dissolving a $\mathrm{Tl}(\mathrm{I})$ $\mathrm{Cl}$ salt $\left(99.999 \%\right.$, Sigma Aldrich $\left.{ }^{\circledR}\right)$ and acidified with diluted ultrapure $\mathrm{HNO}_{3}$. Thallium concentration was confirmed at $4.76 \pm 0.08 \cdot 10^{-4} \mathrm{~mol} \mathrm{~L}^{-1}$ by HR-ICP-MS Element 2 (Thermo Scientific ${ }^{\circledR}$ ) measurements.

\subsection{Reagents}

Every salt solution and then every dilution were made with ultrapure water (milli-Q, 18.2 $\mathrm{M} \Omega \mathrm{cm}^{-2}$, Millipore ${ }^{\circledR}$ ). Salts of $\mathrm{NaCl}$ (VWR Chemical), $\mathrm{CaCl}_{2}$ (VWR Chemical), $\mathrm{NaOH}$ (VWR Chemical) and $\mathrm{Ca}(\mathrm{OH})_{2}$ (VWR Chemical) were used. Acidification was done with ultrapure nitric acid (ULTREX Ultrapure Reagent, J.T. Baker), diluted at appropriate concentrations when needed. Ultima Gold ${ }^{\mathrm{TM}}$ (Perkin Elmer ${ }^{\circledR}$ ) as scintillant was used. Blanks of every solution were analyzed for Tl at HR-ICP-MS Element 2 (Thermo Scientific) and no thallium was detected.

\subsection{Materials and conditioning process}

The clay materials selected for this study are Illite du Puy and a Wyoming smectite. The latter is the montmorillonite extracted from the MX80 bentonite and similar to those previously extensively studied (Baeyens and Bradbury, 1997; Bradbury and Baeyens, 2002, Karnland, 2010). Synthesis of the MX80 bulk mineralogical composition, based on X-ray diffraction analyses, revealed around $83.5 \%$ montmorillonite, $0.7 \%$ illite, $1.1 \%$ gypsum, $2.5 \%$ muscovite, $4.7 \%$ plagioclase, $0.9 \%$ pyrite, $2.8 \%$ quartz and $3.1 \%$ tridymite (Karnland, 2010). The structural formula of this montmorillonite was reported by Guillaume (2002):

$\left(\mathrm{Si}_{3.98} \mathrm{Al}_{0.02}\right)\left(\mathrm{Al}_{1.55} \mathrm{Fe}_{0.09}^{3+} \mathrm{Fe}_{0.08}^{2+} \mathrm{Mg}_{0.28}\right) \mathrm{O}_{10}(\mathrm{OH})_{2} \mathrm{Na}_{0.18} \mathrm{Ca}_{0.10}$ where $\mathrm{Ca}$ and $\mathrm{Na}$ are the natural compensating cations. Illite du Puy was extracted from the Oligocene geological formation located in the region of Le Puy-en-Velay (Haute-Loire, France). Its raw mineralogical composition contains illite with impurities such as kaolinite, carbonates, quartz and feldspars (Gabis, 1958; Van Olphen and 
Fripiat, 1979; Poinssot et al., 1999). Poinssot et al. (1999) reported the structural formula of this illite, $\left(\mathrm{Si}_{3.52} \mathrm{Al}_{0.48}\right)\left(\mathrm{Al}_{1.17} \mathrm{Fe}_{0.49} \mathrm{Mg}_{0.33}\right) \mathrm{O}_{10}(\mathrm{OH})_{2} \mathrm{Na}_{0.12} \mathrm{Ca}_{0.04} \mathrm{~K}_{0.64}$ where $\mathrm{Ca}$, $\mathrm{Na}$ and $\mathrm{K}$ are the natural compensating cations.

Natural illite and smectite were initially purified and conditioned to the homo-ionic Na- and Ca-forms. Raw Illite du Puy and MX80 were finely crushed and suspended in ultrapure water for one night and sieved at $25 \mu \mathrm{m}$. Both $<25 \mu \mathrm{m}$ suspensions were centrifuged. Then, illite du Puy was decarbonized with $\mathrm{HCl} \mathrm{10 \%} \mathrm{(weight,} \mathrm{Merck)} \mathrm{and}$ heated to remove calcite and dolomite. Illite and smectite were dispersed three times each during $24 \mathrm{~h}$ in a $1 \mathrm{M}$ solution of $\mathrm{NaCl}$ or $\mathrm{CaCl}_{2}$. Following this step, they were washed in $\mathrm{NaOH}$ or in $\mathrm{Ca}(\mathrm{OH})_{2}$ solutions at $\mathrm{pH} \sim 8$ overnight. Then, they were rinsed in ultrapure water (milli-Q, Millipore ${ }^{\circledR}$ ) again for $24 \mathrm{~h}$ before suspension in $\mathrm{NaCl}$ or $\mathrm{CaCl}_{2} 10^{-2} \mathrm{M}$ for another $24 \mathrm{~h}$. Finally, conditioned illite and smectite were dispersed in ethanol overnight, dried and crushed. Between each step, illite was centrifuged at $10,596 \mathrm{~g}$ for $30 \mathrm{~min}$ and smectite at $16,556 \mathrm{~g}$ for $45 \mathrm{~min}$.

XRD analyses were performed to check the purity of the final material and confirmed that $<25 \mu \mathrm{m} \mathrm{Ca}$ - and $\mathrm{Na}-$ smectite contained pure montmorillonite with tridymite in trace and $\mathrm{Ca}$ - and $\mathrm{Na}$-illite, mainly illite and significant kaolinite and quartz. Whatever the significant impurities of kaolinite and quartz, their sorption properties are very low compared to illite and consequently are neglected.

Cation exchange capacity (CEC) was measured by K/Cs exchange at $\mathrm{pH}$, firstly conditioned materials were saturated with $\mathrm{K}(1 \mathrm{M} \mathrm{KCl})$ and secondly $\mathrm{K}$ was exchanged with Cs. Then, for smectite the value was $0.896 \pm 0.040$ eq $\mathrm{kg}^{-1}$ whereas it was $0.268 \pm 0.014 \mathrm{eq} \mathrm{kg}^{-1}$ for illite. Exchangeable cations were measured by $\mathrm{Cs}$ exchange at $\mathrm{pH} 8(0.1 \mathrm{M} \mathrm{CsCl}$ and $\mathrm{m} / \mathrm{v}=20 \mathrm{~g} / \mathrm{L})$ Analyses of exchangeable cations revealed that exchangeable $\mathrm{K}$ in conditioned $\mathrm{Ca}$ - and $\mathrm{Na}$-illite was measured under a significant value (less than $0.015 \mathrm{eq} / \mathrm{kg}$ ). Consequently, $\mathrm{K}$ stays fixed in illite interlayer space as compensating cation. Based on cations exchanged analyses, the structural formula of the conditioned smectite and illite studied here are respectively:

$$
\begin{aligned}
& \left(\mathrm{Si}_{3.98} \mathrm{Al}_{0.02}\right)\left(\mathrm{Al}_{1.55} \mathrm{Fe}_{0.09}^{3+} \mathrm{Fe}_{0.08}^{2+} \mathrm{Mg}_{0.28}\right) \mathrm{O}_{10}(\mathrm{OH})_{2} \mathrm{Na}_{0.28} \mathrm{Ca}_{0.04} \\
& \text { and }\left(\mathrm{Si}_{3.98} \mathrm{Al}_{0.02}\right)\left(\mathrm{Al}_{1.55} \mathrm{Fe}_{0.09}^{3+} \mathrm{Fe}_{0.08}^{2+} \mathrm{Mg}_{0.28}\right) \mathrm{O}_{10}(\mathrm{OH})_{2} \mathrm{Ca}_{0.30} \\
& \left(\mathrm{Si}_{3.52} \mathrm{Al}_{0.48}\right)\left(\mathrm{Al}_{1.17} \mathrm{Fe}_{0.49} \mathrm{Mg}_{0.33}\right) \mathrm{O}_{10}(\mathrm{OH})_{2} \mathrm{Na}_{0.10} \mathrm{~K}_{0.64} \text { and } \\
& \left(\mathrm{Si}_{3.52} \mathrm{Al}_{0.48}\right)\left(\mathrm{Al}_{1.17} \mathrm{Fe}_{0.49} \mathrm{Mg}_{0.33}\right) \mathrm{O}_{10}(\mathrm{OH})_{2} \mathrm{Ca}_{0.10} \mathrm{~K}_{0.64}
\end{aligned}
$$

The residual layer charges are then compensated by protons.

At neutral $\mathrm{pH}(\sim 7)$ in bulk solution, blanks of thallium released (in duplicates) by conditioned materials were performed and the bulk solution was analyzed with HR-ICPMS Element 2 (Thermo Scientific) after six days of contact time. The Tl content in material was $2.50 \pm 2.11 \cdot 10^{-8} \mathrm{~mol}$ $\mathrm{kg}^{-1}$ in Na-smectite, $8.62 \pm 0.34 \cdot 10^{-9} \mathrm{~mol} \mathrm{~kg}^{-1}$ in Casmectite, $\quad 1.06 \pm 1.03 \cdot 10^{-10} \mathrm{~mol} \mathrm{~kg}^{-1}$ in Na-illite and $1.52 \pm 0.08 \cdot 10^{-9} \mathrm{~mol} \mathrm{~kg}^{-1}$ in Ca-illite. Total thallium concentrations measured in the supernatant during batch experiments were therefore corrected according to the latest values.

\section{4. ${ }^{204} \mathrm{Tl}$ measurement by liquid scintillation}

The $\beta$ emission of ${ }^{204} \mathrm{Tl}$ radioisotope was used to measure ${ }^{204} \mathrm{Tl}$ activity in every sample by liquid scintillation counting. Thus, $1 \mathrm{~mL}$ of solution was sampled and displayed in $4 \mathrm{~mL}$ of UltimaGold ${ }^{\mathrm{TM}}$ scintillant. The scintillation counter used was a PACKARD Tricarb 2700. Before experiments, the source solution was measured three times with this protocol. The measured activity was compared to the expected activity and a yield of $97 \%$ was calculated. Then, each measured activity during experiments was corrected with the latest yield.

\subsection{Stable thallium measurement}

Solutions with only stable isotopes were analyzed by using an HR-ICP-MS Element 2 (Thermo Scientific) in a clean room at mass 205 in low resolution. A solution of ${ }^{115}$ In $(5 \mathrm{ppb})$ served as an internal standard. Dilutions of samples, when needed, as well as standard preparations were made with distilled nitric acid. Final solutions were in a matrix of $1.0-1.5 \%$ (weight) of $\mathrm{HNO}_{3}$. Calibration standards were diluted from a thallium ICP standard solution (TraceCERT ${ }^{\circledR}$, Sigma Aldrich ${ }^{\circledR}$ ) Certified solutions TM23.4 (Environment Canada) validated $\mathrm{Tl}$ analysis and calibration. The limit of detection was $7.5 \cdot 10^{-13} \mathrm{~mol} \mathrm{~L}^{-1}$ and limit of quantification was $2.5 \cdot 10^{-12} \mathrm{~mol} \mathrm{~L}^{-1}$.

\subsection{Sorption isotherms}

The effects of concentrations and $\mathrm{pH}$ on sorption were investigated by sorption isotherms and conducted for each matrix, Na-illite, Ca-illite, Na-smectite and Ca-smectite. At each step, batches were weighed in order to precisely calculate each solution component's concentration.

Firstly, $100 \mathrm{mg}$ of solid material was dispersed in $5 \mathrm{~mL}$ of bulk solution at $10 \mathrm{mM}\left(\mathrm{CaCl}_{2}\right.$ or $\left.\mathrm{NaCl}\right)$ in a $10 \mathrm{~mL}$ ultracentrifuge tube in Nalgene (Oak Ridge Centrifuge Tube, Thermo Scientific). Tubes were sequentially weighed in order to maintain a constant mass over volume ratio in each batch. Then, acidic pHs were adjusted with $50 \mu \mathrm{L}$ of $\mathrm{HNO}_{3}$ diluted at needed concentrations to introduce the proper amount of protons for every targeted $\mathrm{pH}$, taking into account the additional protons coming from $\mathrm{Tl}$ solutions and radiotracer solution. Basic $\mathrm{pHs}$ were adjusted with $50-200 \mu \mathrm{L}$ of $\mathrm{NaOH} 0.1 \mathrm{M}$ solution for $\mathrm{Na}$ matrices while $120-1500 \mu \mathrm{L}$ of $\mathrm{Ca}(\mathrm{OH})_{2} \quad 0.01 \mathrm{M}$ solution were used in $\mathrm{Ca}$ matrixes. This solution was previously bubbled with $\mathrm{N}_{2}$ gas to avoid carbonate precipitation.

In order to optimize the measurement uncertainty of ${ }^{204} \mathrm{Tl}$ in solution at equilibrium, stable and radiotracer concentrations introduced were based on results obtained on Cs sorption towards illite and smectite under similar physico-chemical conditions, extracted from literature (Poinssot et al., 1999; Missana et al., 2014a; Wissocq et al., in press). Higher sorption was estimated onto illite than smectite as well as higher cation exchange in $\mathrm{Na}^{+}$ media than in $\mathrm{Ca}^{2+}$ media. Consequently, amounts of stable $\mathrm{Tl}$ and radioisotope were optimized considering the matrices nature and background solutions. 
For $\mathrm{pH}$ isotherms with illite, $50 \mu \mathrm{L}$ of a stable $\mathrm{Tl}$ solution at $4.66 \pm 0.08 \cdot 10^{-6} \mathrm{~mol} \mathrm{~L}^{-1}$ was added to increase total thallium in solution. Then $100 \mu \mathrm{L}$ of radiotracer solution (solution 1: $1.01 \mathrm{MBq}$ in $0.1 \mathrm{M} \mathrm{HCl}$ ) was introduced in batches with $\mathrm{Na}$ matrices and $50 \mu \mathrm{L}$ in batches with $\mathrm{Ca}$ matrices.

For concentration isotherms with illite, eight stable $\mathrm{Tl}$ solutions (concentrations in SI, Table S1) were used to create a range of $\mathrm{Tl}$ concentrations from $2.52 \pm 0.11 \cdot 10^{-10}$ to $8.39 \pm 0.15 \cdot 10^{-6} \mathrm{~mol} \mathrm{~L}^{-1}$ for concentration isotherms. Depending on background solution, stable $\mathrm{Tl}$ solutions added were 50 or $100 \mu \mathrm{L}$. Finally, $100 \mu \mathrm{L}$ or $50 \mu \mathrm{L}$ of radiotracer (solution 1) was introduced in $\mathrm{Na}$ and $\mathrm{Ca}$ bulk solutions respectively. Only radiotracer was used to label the two batches containing the lowest $\mathrm{Tl}$ concentrations. $\mathrm{pH}$ was only imposed by the buffering capacity of illite.

The operating condition was basically the same applied for experiments with Wyoming smectite, except that no stable $\mathrm{Tl}$ was added in solutions for $\mathrm{pH}$ isotherm experiments due to its estimated lower sorption ability than illite. Radiotracer (solution 2: $0.99 \mathrm{MBq}$ in $0.1 \mathrm{M} \mathrm{HCl}$ ) volumes were $50 \mu \mathrm{L}$ for every experiment independently of the bulk solutions or the type of isotherms. Total $\mathrm{Tl}$ concentrations (between $2.52 \pm 0.06 \cdot 10^{-10}$ and $1.04 \pm 0.02 \cdot 10^{-5} \mathrm{~mol}$ $\mathrm{L}^{-1}$ ) introduced in concentration isotherms were adjusted by adding $50-100 \mu \mathrm{L}$ of eight different $\mathrm{Tl}$ solutions (SI, Table S1). pH was only imposed by the buffering capacity of smectite.

After six days of continuous shaking at room temperature, tubes were ultra-centrifuged (Beckman Coulter Optima XPN-80 ultracentrifuge with a Type Ti70 rotor) for $45 \mathrm{~min}$ at $10,596 \mathrm{~g}$ for illite and $16,556 \mathrm{~g}$ for smectite. Then, $\mathrm{pH}( \pm 0.10)$ was measured (for each tube) using a combined glass $\mathrm{pH}$ microelectrode (Metrohm) incorporating an $\mathrm{Ag} / \mathrm{AgCl}$ reference electrode. Electrode calibration was made with buffer solutions (Certipur ${ }^{\circledR}$, Merck) at $\mathrm{pH}$ 4.01, 7.00 and 12.00 . $1 \mathrm{~mL}$ of supernatant was sampled and mixed with $4 \mathrm{~mL}$ of scintillant. Finally, ${ }^{204} \mathrm{Tl}$ activity was measured by liquid scintillation.

\subsection{Desorption isotherms}

$\mathrm{Tl}$ sorption reversibility was also studied on experiments performed on the four materials. As reversibility, we attempted to verify that the desorption reaction at equilibrium remained the same solid to solution partitioning as obtained with sorption reaction under the same chemical conditions. Following the sorption isotherm, the remaining supernatant was removed. Then, the residual solids and small liquid fraction (as hydrated clays minerals) were weighted. Bulk solutions $\left(10^{-2} \mathrm{M} \mathrm{CaCl}_{2}\right.$ or $\left.10^{-2} \mathrm{M} \mathrm{NaCl}\right)$ were added with acid/base solutions to adjust $\mathrm{pH}$ to be as close as possible to those imposed in sorption isotherms. Volumes were calculated to keep the same solid/solution ratio as in sorption experiments. Lastly, tubes were shaken continuously during six days and then, centrifuged and sampled following the same procedure described in the sorption isotherms section.

Desorption isotherms are necessary to check the sorption reversibility. Thus, cation exchange is verified as expressed in Eqs. (6), (9)-(11) (see below). Respecting this condition, the thermodynamic multi-site ion exchanger model may be applied.

\subsection{Sorption kinetics}

Kinetics of $\mathrm{Tl}$ sorption onto illite and smectite in all tested matrices $(\mathrm{Na}$ and $\mathrm{Ca}$ ) were performed to determine the time to achieve equilibrium. Batch experiments used the same polycarbonate centrifuge tube as in the isotherms experiments and were done using stable Tl. Thus, $100 \mathrm{mg}$ of conditioned clay minerals were dispersed in $5 \mathrm{~mL}$ of $\mathrm{CaCl}_{2}$ or $\mathrm{NaCl}$ at $10 \mathrm{mmol} \mathrm{L}^{-1}$. Duplicates were performed at a set of contact times. Tested contact times were $0,2,6,10$ and 15 days for Ca-illite and Na-illite. They were 0, 2, 7, 11 and 15 days for $\mathrm{Ca}$-smectite ad $\mathrm{Na}$-smectite. Initial $\mathrm{Tl}$ concentrations were $\sim 1.0 \cdot 10^{-7} \mathrm{~mol} \mathrm{~L}^{-1}$. $\mathrm{pH}$ was imposed using the buffering capacity of conditioned illite and smectite. Solutions were shaken continuously. At each investigated time, tubes were centrifuged (as in Section 2.7). Details of experimental conditions and figures are presented in supporting information (Figs. S2 and S3). Sorbed concentrations achieved equilibrium in all cases within 2 days. To insure time to equilibrium, in all isotherms experiments, contact time was imposed at six days.

\subsection{Calculations of experimental parameters}

Both sorption and desorption isotherm (experimental) results are expressed in term of distribution coefficient, calculated following Eq. (1):

$K_{\mathrm{d}}=\frac{\mathrm{A}_{\text {ini }}-\mathrm{A}_{\text {sup }, \text { eq }}}{\mathrm{A}_{\text {sup }, \text { eq }}} \times \frac{\mathrm{V}}{\mathrm{m}}$

where $K_{\mathrm{d}}$ is expressed in $\mathrm{L} \mathrm{kg}^{-1}$. $\mathrm{A}_{\text {ini }}(\mathrm{Bq})$ is the initial activity of the solution and $\mathrm{A}_{\text {sup,eq }}$ (in $\mathrm{Bq}$ ) is the supernatant solution activity calculated with the measured activity of $1 \mathrm{~mL}$ of supernatant $\left(\mathrm{A}_{\text {mes}}\right.$, Eq. (2), in $\left.\mathrm{Bq} \mathrm{L}^{-1}\right)$ reported to the total solution volume $\mathrm{V}$ (in $\mathrm{L}$ ).

$\mathrm{A}_{\text {sup }, \mathrm{eq}}=\mathrm{A}_{\text {mes }} \times \mathrm{V}$

Then $\mathrm{m}$ (in $\mathrm{kg}$ ) is the dry mass of conditioned clay minerals. In this study, $\mathrm{V} / \mathrm{m}$ was maintained constant at $50.0 \pm 3.8 \mathrm{~L}$ $\mathrm{kg}^{-1}$. Eq. (1) can be simplified in Eq. (3). The corresponding equation with thallium concentration is also reported in Eq. (3).

$K_{\mathrm{d}}=\left(\frac{\mathrm{A}_{\text {ini }}}{\mathrm{A}_{\text {sup }, \text { eq }}}-1\right) \times \frac{\mathrm{V}}{\mathrm{m}}=\left(\frac{[\mathrm{Tl}]_{\mathrm{t}=0}}{[\mathrm{Tl}]_{\text {free }, \mathrm{eq}}}-1\right) \times \frac{\mathrm{V}}{\mathrm{m}}$

$[\mathrm{Tl}]_{\text {free,eq }}\left(\mathrm{mol} \mathrm{L}^{-1}\right)$ is the thallium concentration in the supernatant at equilibrium. It is the sum of ${ }^{204} \mathrm{Tl}$ radiotracer and of the stable thallium concentrations in solution. Details of its calculations are provided in supporting information $(\mathrm{SI})$. $[\mathrm{Tl}]_{\mathrm{t}=0}$ (in $\mathrm{mol} \mathrm{L}^{-1}$ ) corresponds to the thallium concentration at the beginning of each experiments. $[\mathrm{Tl}]_{\text {sorbed }}$ in $\mathrm{mol} \mathrm{kg}^{-1}$ was also calculated as in Eq. (4).

$[\mathrm{Tl}]_{\text {sorbed }}=K_{\mathrm{d}} \times[\mathrm{Tl}]_{\text {free,eq }}$ 
Two blank sets were associated with each sorption isotherms and contained only bulk solutions $\left(\mathrm{CaCl}_{2}\right.$ or $\mathrm{NaCl}$ $10 \mathrm{mmol} \mathrm{L}^{-1}$ ), radiotracers and when necessary stable thallium solutions. They were used as reference to calculate, for each isotherm, the initial $\mathrm{Tl}$ concentration $\left([\mathrm{Tl}]_{\mathrm{t}=0}\right)$ considering the ${ }^{204} \mathrm{Tl}$ source activity diluted in batch samples $\left(\mathrm{A}_{\mathrm{ini}}\right)$. More details of equations and associated corrections for sorption and desorption isotherms are presented in SI.

\subsection{Estimation of experimental uncertainties}

Uncertainties reported in this section have only been calculated from the propagation of known measurements or lab errors following the same approach as Reinoso-Maset and Ly (2014). However, these are missing the variability in minerals properties. Experimental errors were hence calculated for each batch following the propagation errors theory. The variance of a $\mathrm{G}$ function of different $\mathrm{x}_{i}$ variable can be calculated from the variances of the variables $\mathrm{x}_{i}$ using this expression:

$\sigma_{G}^{2}=\sum_{i=1}^{n}\left(\frac{\partial G}{\partial x_{i}}\right)^{2} \sigma_{i}^{2}+2 \sum_{i} \sum_{j} \frac{\partial G}{\partial x_{i}} \frac{\partial G}{\partial x_{j}} \sigma_{i j}$

where $\left(\partial \mathrm{G} / \partial \mathrm{x}_{i}\right)$ is the partial derivative of $\mathrm{G}$ with respect to $\mathrm{x}_{i}, \sigma^{2}$ is the variance of $\mathrm{x}_{\mathrm{i}}$ and $\sigma_{i j}$ the covariance of the $\mathrm{x}_{i}$ and $\mathrm{x}_{j}$ variables. If these variables are independents, the covariance term is then equal to zero. In this study, log $K_{\mathrm{d}}\left(\right.$ in $\left.\log \left(\mathrm{L} \mathrm{kg}^{-1}\right)\right)$ experimental errors were between 0.01 and $0.05 \log$ units for illite and between 0.01 and 0.07 for smectite. $\log [\mathrm{Tl}]_{\text {free,eq }}\left(\right.$ in $\left.\log \left(\mathrm{mol} \mathrm{L}^{-1}\right)\right)$ experimental errors were from 0.02 to $0.07 \mathrm{log}$ units. Finally, errors on $\log$ $[\mathrm{Tl}]_{\text {sorbed }}$ (in $\log \left(\mathrm{mol} \mathrm{kg}^{-1}\right)$ ) were between 0.02 and 0.09 $\log$ units for illite and from 0.03 to $0.05 \log$ units for smectite. Sets of repeated measurements indicated that $\pm 0.17 \mathrm{log}$ units for illite and $\pm 0.16 \log$ units for smectite yielded the spread in $\log K_{\mathrm{d}}$ values. Those values were taken as error bars values. $[\mathrm{Tl}]_{\text {sorbed }}$ is calculated with the distribution coefficient and $[\mathrm{Tl}]_{\text {free,eq }} . K_{\mathrm{d}}$ having the highest variability compared to $[\mathrm{Tl}]_{\text {free,eq }}$, its spread was used to consider $[\mathrm{Tl}]_{\text {sorbed }}$ error. Consequently, errors bars for $[\mathrm{Tl}]_{\text {sorbed }}$ are $\pm 0.17 \log$ units for illite and $\pm 0.16 \log$ units for smectite.

For $\mathrm{pH}$, uncertainties for each measurement are \pm 0.10 $\mathrm{pH}$ unit. In results, for $\mathrm{pH}$ isotherms, due to measurement in each batch, the latest value is taken as error. However, for $\mathrm{pH}$ related to concentration isotherms, averages are displayed. Then, errors are standard deviations of series averaged.

\section{MULTI-SITE ION EXCHANGER MODEL}

The Multi-Site Ion Exchanger model is based on the thermodynamics of chemical equilibria, and considers minerals as ion-exchangers described by negatively charged adsorption sites. For a complete description of the approach, readers can refer to Gorgeon (1994); Motellier et al. (2003); Jacquier et al. (2004) and Wissocq et al. (in press). This theory is only based on a macroscopic description, and does not consider any structural hypothesis of minerals (Motellier et al., 2003). Thus, the exchange behav- ior of each cation (here, $\mathrm{Na}^{+}, \mathrm{Ca}^{2+}$ and $\mathrm{Tl}^{+}$) has to be studied individually as a function of $\mathrm{pH}$ and concentration on purified clay minerals (Motellier et al., 2003; Jacquier et al., 2004). Then, $\mathrm{H}^{+}$are taken as reference cations (Motellier et al., 2003).

Classically, cation exchange between $\mathrm{H}^{+}$and $\mathrm{M}^{\mathrm{m}+}$ for a given sites $\mathrm{X}_{\mathrm{i}}^{-}$is expressed by Eq. (6).

$$
\left\{\left(\mathrm{X}_{\mathrm{i}}^{-}\right)_{\mathrm{m}}-\mathrm{M}^{\mathrm{m}+}\right\}+\mathrm{mH}^{+} \leftrightarrow \mathrm{m}\left\{\mathrm{X}_{\mathrm{i}}^{-}-\mathrm{H}^{+}\right\}+\mathrm{M}^{\mathrm{m}+}
$$

Then, the equilibrium constant of this reaction is written as follow in Eq. (7):

$$
\begin{aligned}
\mathrm{K}_{\mathrm{M}^{\mathrm{m}+} / \mathrm{H}^{+}}^{\mathrm{i}} & =\frac{\left(\mathrm{X}_{\mathrm{i}}^{-}-\mathrm{H}^{+}\right)^{\mathrm{m}}\left(\mathrm{M}^{\mathrm{m}+}\right)}{\left(\left(\mathrm{X}_{\mathrm{i}}^{-}\right)_{\mathrm{m}}-\mathrm{M}^{\mathrm{m}+}\right)\left(\mathrm{H}^{+}\right)^{\mathrm{m}}} \\
& =\frac{\left[\mathrm{X}_{\mathrm{i}}^{-}-\mathrm{H}^{+}\right]^{\mathrm{m}}\left[\mathrm{M}^{\mathrm{m}+}\right] f_{\left(\mathrm{X}_{\mathrm{i}}^{-}-\mathrm{H}^{+}\right)}^{\mathrm{m}} \gamma_{\mathrm{M}^{\mathrm{m}+}}}{\left[\left(\mathrm{X}_{\mathrm{i}}^{-}\right)_{\mathrm{m}} \mathrm{M}^{\mathrm{m}+}\right]\left[\mathrm{H}^{+}\right]^{\mathrm{m}} f_{\left(\left(\mathrm{X}_{\mathrm{i}}^{-}\right)_{\mathrm{m}} \mathrm{M}^{\mathrm{m}+}\right)} \gamma_{\mathrm{H}^{+}}^{\mathrm{m}}}
\end{aligned}
$$

where $\mathrm{K}^{\mathrm{i}}$ is the selectivity coefficient, $i$ is the type of sorption site. () and [] represent activities and concentrations of species, respectively. Species in solution are in $\mathrm{mol} \mathrm{L}^{-1}$ whereas adsorbed species are in mol kg-1 (of dry clay mineral). $f$ (in $\mathrm{kg} \mathrm{mol}^{-1}$ ) is the activity coefficient of each adsorbed species and $\gamma$ (in $\mathrm{L} \mathrm{mol}^{-1}$ ) is the activity coefficient of the species in solution. All $f$ 's are unknown but their ratios are expected to be constant. Consequently, a corrected selectivity coefficient $\left(\mathrm{K}_{\mathrm{M}^{\mathrm{m}+} / \mathrm{H}^{+}}^{* \mathrm{~m}}\right)$ is calculated (Eq. (8)). Activity coefficients for species in solution are calculated according to Davis theory.

$\mathrm{K}_{\mathrm{M}^{\mathrm{m}+} / \mathrm{H}^{+}}^{*}=\frac{\left[\mathrm{X}_{\mathrm{i}}^{-}-\mathrm{H}^{+}\right]^{\mathrm{m}}\left[\mathrm{M}^{\mathrm{m}+}\right] \gamma_{\mathrm{M}^{\mathrm{m}+}}}{\left[\left(\mathrm{X}_{\mathrm{i}}^{-}\right)_{\mathrm{m}}-\mathrm{M}^{\mathrm{m}+}\right]\left[\mathrm{H}^{+}\right]^{\mathrm{m}} \gamma_{\mathrm{H}^{+}}^{\mathrm{m}}}$

In this study, three cations are in solution, $\mathrm{Tl}^{+}, \mathrm{Na}^{+}$or $\mathrm{Ca}^{2+}$, each exchanging with $\mathrm{H}^{+}$according to Eqs. (9)-(11). In our experimental physico-chemical conditions, thallium is expected only in free form, $\mathrm{Tl}^{+}$, avoiding some hydroxide forms of thallium (Fig. 1 and SI, Fig. S1). So a correction with Ringböm coefficient (Jacquier et al., 2004; Tertre et al., 2009) is neglected.

$$
\begin{aligned}
& \left\{\left(\mathrm{X}_{\mathrm{i}}^{-}\right)-\mathrm{Tl}^{+}\right\}+\mathrm{H}^{+} \leftrightarrow\left\{\mathrm{X}_{\mathrm{i}}^{-}-\mathrm{H}^{+}\right\}+\mathrm{Tl}^{+} \\
& \left\{\left(\mathrm{X}_{\mathrm{i}}^{-}\right)-\mathrm{Na}^{+}\right\}+\mathrm{H}^{+} \leftrightarrow\left\{\mathrm{X}_{\mathrm{i}}^{-}-\mathrm{H}^{+}\right\}+\mathrm{Na}^{+} \\
& \left\{\left(\mathrm{X}_{\mathrm{i}}^{-}\right)_{2}-\mathrm{Ca}^{2+}\right\}+2 \mathrm{H}^{+} \leftrightarrow 2\left\{\mathrm{X}_{\mathrm{i}}^{-}-\mathrm{H}^{+}\right\}+\mathrm{Ca}^{2+}
\end{aligned}
$$

Therefore, selectivity coefficients are calculated as follows:

$\mathrm{K}_{\mathrm{Tl}^{+} / \mathrm{H}^{+}}^{* \mathrm{i}}=\frac{\left[\mathrm{X}_{\mathrm{i}}^{-}-\mathrm{H}^{+}\right]\left[\mathrm{Tl}^{+}\right] \gamma_{\mathrm{Tl}^{+}}}{\left[\mathrm{X}_{\mathrm{i}}^{-}-\mathrm{Tl}^{+}\right]\left[\mathrm{H}^{+}\right] \gamma_{\mathrm{H}^{+}}}$

$\mathrm{K}_{\mathrm{Na}^{+} / \mathrm{H}^{+}}^{* \mathrm{i}}=\frac{\left[\mathrm{X}_{\mathrm{i}}^{-}-\mathrm{H}^{+}\right]\left[\mathrm{Na}^{+}\right] \gamma_{\mathrm{Na}^{+}}}{\left[\mathrm{X}_{\mathrm{i}}^{-}-\mathrm{Na}^{+}\right]\left[\mathrm{H}^{+}\right] \gamma_{\mathrm{H}^{+}}}$

$\mathrm{K}_{\mathrm{Ca}^{2+} / 2 \mathrm{H}^{+}}^{* \mathrm{i}}=\frac{\left[\mathrm{X}_{\mathrm{i}}^{-}-\mathrm{H}^{+}\right]^{2}\left[\mathrm{Ca}^{2+}\right] \gamma_{\mathrm{Ca}^{2+}}}{\left[\left(\mathrm{X}_{\mathrm{i}}^{-}\right)_{2}-\mathrm{Ca}^{2+}\right]\left[\mathrm{H}^{+}\right]^{2} \gamma_{\mathrm{H}^{+}}^{2}}$

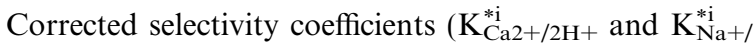
$\mathrm{H}+$ ) of each $\mathrm{X}_{\mathrm{i}}$ sorption site characterizing the four matrices (Ca-illite, Ca-smectite, Na-illite and Na-smectite) are acquired in $10 \mathrm{mmol} \mathrm{L}^{-1}$ solutions (Wissocq et al., in press), while those of $\mathrm{Tl}^{+}$required estimation. Compiled 
Table 1

Sites capacity and selectivity coefficients calculated in this study. Equations for $\log \mathrm{K}_{\mathrm{Tl}^{+} / \mathrm{Na}^{+}}^{* \mathrm{i}}$ and $\log \mathrm{K}_{2 \mathrm{Tl}^{+} / \mathrm{Ca}^{2+}}^{* \mathrm{i}}$, not used during modelling, were calculated by combining selectivity coefficients with protons as reported in SI (Eqs. S9 and S10).

\begin{tabular}{|c|c|c|c|c|c|c|c|}
\hline$\underline{\text { Mineral }}$ & Sites & $\mathrm{CE}_{\mathrm{i}}\left(\right.$ eq kg $^{-1}$ ) & $\log \mathrm{K}_{\mathrm{Tl}^{+} / \mathrm{H}^{+}}^{* \mathrm{i}}$ & $\log \mathrm{K}_{\mathrm{Na}^{+} / \mathrm{H}^{+}}^{* \mathrm{C}}$ & $\log \mathrm{K}_{\mathrm{Ca}^{2+} / 2 \mathrm{H}^{+}}^{\mathrm{C}}$ & $\log \mathrm{K}_{\mathrm{Tl}^{+} / \mathrm{Na}^{+}}^{* \mathrm{i}}$ & $\log \mathrm{K}_{2 \mathrm{Tl}^{+} / \mathrm{Ca}^{2+}}^{* \mathrm{i}}$ \\
\hline \multirow[t]{5}{*}{ Illite } & $\mathrm{X}_{0}$ & $2.5 \cdot 10^{-4}$ & $-3.87 \pm 0.03$ & $0.87 \pm 0.14$ & $0.40 \pm 1.98$ & $-4.74 \pm 0.77$ & $-3.97 \pm 19.50$ \\
\hline & $X_{1}$ & $0.13^{\mathrm{A}}$ & $0.18 \pm 0.05$ & $2.77 \pm 0.13$ & $2.17 \pm 0.07$ & $-2.60 \pm 0.79$ & $-1.69 \pm 0.49$ \\
\hline & $\mathrm{X}_{2}$ & $0.04^{\mathrm{A}}$ & $1.13 \pm 0.11$ & $4.19 \pm 0.18$ & $4.31 \pm 0.272$ & $-3.07 \pm 0.44$ & $-2.88 \pm 0.39$ \\
\hline & $\mathrm{X}_{3}$ & $0.07^{\mathrm{A}}$ & $6.20 \pm 1.03$ & $8.95 \pm 3.78$ & $11.75 \pm 0.21$ & $-2.75 \pm 1.62$ & $-5.24 \pm 0.96$ \\
\hline & $\sum C E_{i}$ & 0.25 & & & & & \\
\hline \multirow[t]{5}{*}{ Smectite } & $\mathrm{X}_{\mathrm{s}}$ & $2.0 \cdot 10^{-4}$ & $-2.31 \pm 0.25$ & $2.59 \pm 0.23$ & $0.22 \pm 0.18$ & $-4.90 \pm 0.95$ & $-2.23 \pm 2.10$ \\
\hline & $X_{a}$ & $0.39^{\mathrm{B}}$ & $0.13 \pm 0.81$ & $0.26 \pm 0.04$ & $0.49 \pm 0.49$ & $-0.14 \pm 0.92$ & $-0.06 \pm 0.45$ \\
\hline & $\mathrm{X}_{\mathrm{b}}$ & $0.36^{\mathrm{B}}$ & $1.52 \pm 0.29$ & $2.62 \pm 0.089$ & $4.35 \pm 0.03$ & $-1.10 \pm 0.25$ & $-2.53 \pm 0.50$ \\
\hline & $\mathrm{X}_{\mathrm{c}}$ & $0.14^{\mathrm{B}}$ & $6.35 \pm 0.21$ & $8.45 \pm 0.18$ & $14.84 \pm 0.06$ & $-2.10 \pm 0.12$ & $-8.19 \pm 0.31$ \\
\hline & $\sum C E_{i}$ & 0.89 & & & & & \\
\hline
\end{tabular}

${ }^{\text {A }}$ From Gorgeon (1994).

${ }^{\text {B }}$ From Nolin (1997).

C From Wissocq et al. (in press).

data from a previous study were used and are recapitulated in Table 1. In this study, only $\mathrm{Tl}$ selectivity coefficients with reference to protons were adjusted from both sorption curves over $\mathrm{pH}$ and over concentration by non-linear regression using Excel solver. Uncertainties of selectivity coefficient obtained by Excel solver were calculated with the Excel macro SolverAid. Results are given in Table 1. Finally, $\mathrm{K}_{2 \mathrm{~T} 1+/ \mathrm{Ca} 2+}^{* \mathrm{i}}$ and $\mathrm{K}_{\mathrm{T} 1+/ \mathrm{Na}+}^{* \mathrm{i}}$ (not used during modelling) were calculated by combining selectivity coefficients with protons as reported in SI (Eqs. S9 and S10) while their uncertainties was estimated with error propagation (Eq. (5)).

Cations, here $\mathrm{Tl}^{+}, \mathrm{Na}^{+}$and $\mathrm{H}^{+}$or $\mathrm{Tl}^{+}, \mathrm{Ca}^{2+}$ and $\mathrm{H}^{+}$, can saturate a sorption site $\mathrm{X}_{\mathrm{i}}^{-}$capacity (Tertre et al., 2009). The capacity of major sorption sites are generally deduced from experimental saturation curves, implying cation in major concentration (i.e. $\mathrm{Na}^{+}, \mathrm{Ca}^{2+}, \mathrm{H}^{+}$). Those sites are characterized by plateau in $\mathrm{pH}$ isotherms when saturation occurs. Thus, site capacity, $\mathrm{CE}_{\mathrm{i}}$, is calculated with the sum of adsorbed species (Eqs. (15) and (16)).

$$
\begin{aligned}
& \mathrm{CE}_{\mathrm{i}}=\left[\mathrm{X}_{\mathrm{i}}^{-}-\mathrm{Tl}^{+}\right]+\left[\mathrm{X}_{\mathrm{i}}^{-}-\mathrm{Na}^{+}\right]+\left[\mathrm{X}_{\mathrm{i}}^{-}-\mathrm{H}^{+}\right] \\
& \mathrm{CE}_{\mathrm{i}}=\left[\mathrm{X}_{\mathrm{i}}^{-}-\mathrm{Tl}^{+}\right]+2\left[\left(\mathrm{X}_{\mathrm{i}}^{-}\right)_{2}-\mathrm{Ca}^{2+}\right]+\left[\mathrm{X}_{\mathrm{i}}^{-}-\mathrm{H}^{+}\right]
\end{aligned}
$$

Sorbed cation concentrations may be expressed by relations according to cation valence of electrolyte, and taking into account $\mathrm{pH}, \mathrm{CEC}$, corrected selectivity coefficient (for $\mathrm{Ca}^{2+}$ and $\mathrm{Na}^{+}$) (Wissocq et al., in press). In case of trace element, as for thallium competing with major element, sorbed concentration is directly estimated from experimental results (Eq. (4)). The capacity of low capacity sites are then determined on experimental data expressed in terms of sorbed concentration versus concentration in solution at equilibrium or by fitting the combination of Eqs. (12)(16) on experimental isotherms. In case of multi-sites, the sum of $\mathrm{CE}_{\mathrm{i}}$ has to be equal to the exchange capacity (CEC) of the clay minerals. Given that sorption properties of illite du Puy and Wyoming smectite were extensively studied and our conditioned clay CEC comparable to those of previous studies, the $\mathrm{CE}_{\mathrm{i}}$ of major sorption sites are those determined by Gorgeon (1994) for illite and Nolin
(1997) for smectite. Usually, three major sorption sites are used to describe the illite exchanger (Brouwer et al., 1983). However, it is common to add a fourth site, of lower capacity and higher affinity to describe experimental data (Maes et al., 1985) both on illite (Savoye et al., 2012) and on smectite (Maes et al., 1985; Tertre et al., 2009).

In this study, four sites were necessary to model experimental data: three major sites and one minor site with high affinity and low capacity (noted $\mathrm{X}_{0}$ or $\mathrm{X}_{\mathrm{s}}$ ). The latest was estimated with graphs support (Fig. 2A and B) by considering the slope break of the $\log [\mathrm{Tl}]_{\text {sorbed }}$ vs. $\log [\mathrm{Tl}]_{\text {free,eq }}$ curves (Poinssot et al., 1999; Missana et al., 2014a). The value of $\log [\mathrm{Tl}]_{\text {sorbed }}$ read (arrows in Fig. $2 \mathrm{~A}$ and $\mathrm{B}$ ) at the slope break is used as $\mathrm{X}_{0}$ and $\mathrm{X}_{\mathrm{s}}$ site capacity and refinedbydjustingsimultaneouslythißEandhe

$\mathrm{K}_{\mathrm{T} 1+/ \mathrm{H}+}^{* \mathrm{i}}$ of four sites for $\mathrm{pH}$ and concentration isotherms. For each mineral, data from all matrices (Na-illite and $\mathrm{Ca}$-illite on one hand and $\mathrm{Na}$-smectite and $\mathrm{Ca}$-smectite on another hand) were treated together. Consequently, $\mathrm{CE}_{\mathrm{i}} \mathrm{s}$ for $\mathrm{X}_{0}$ or $\mathrm{X}_{\mathrm{s}}$ were adjusted as one as they are intrinsic properties of minerals and cannot depend on the conditioning state $(\mathrm{Na}$ or $\mathrm{Ca}) . \mathrm{CE}_{\mathrm{i}}$ values for major sites $\left(\mathrm{X}_{1}, \mathrm{X}_{2}\right.$ and $\mathrm{X}_{3}$ or $\mathrm{X}_{\mathrm{a}}, \mathrm{X}_{\mathrm{b}}$ and $\mathrm{X}_{\mathrm{c}}$ ) determined by Gorgeon (1994) and Nolin (1997) are summarized in Table 1 and were taken as published and unadjustable.

\section{RESULTS}

\subsection{Sites descriptions and selectivity coefficient for thallium}

In the case of $\mathrm{Tl}$, illite and smectite have to be described as cation exchangers with four sites. Although, smectite expresses a larger cation exchange capacity than illite (Table 1$)$, the estimated minor sites capacities $\left(\mathrm{X}_{\mathrm{s}}\right.$ and $\left.\mathrm{X}_{0}\right)$ are close for both clay minerals, reaching 0.20 meq kg-1 and $0.25 \mathrm{meq} \mathrm{kg}^{-1}$, respectively (Table 1 ). Their capacities were estimated graphically on $\log [\mathrm{Tl}]_{\text {sorbed }}$ vs. Log $[\mathrm{Tl}]_{\text {eq }}$ curves, at the slope break (pointed by arrows) in Fig. $2 \mathrm{~A}$ for smectite and $2 \mathrm{~B}$ for illite. In this study, shifts are small but more obvious when $\mathrm{Na}^{+}$is the background cation (Fig. 2A and B). It corresponds to site saturations by the 

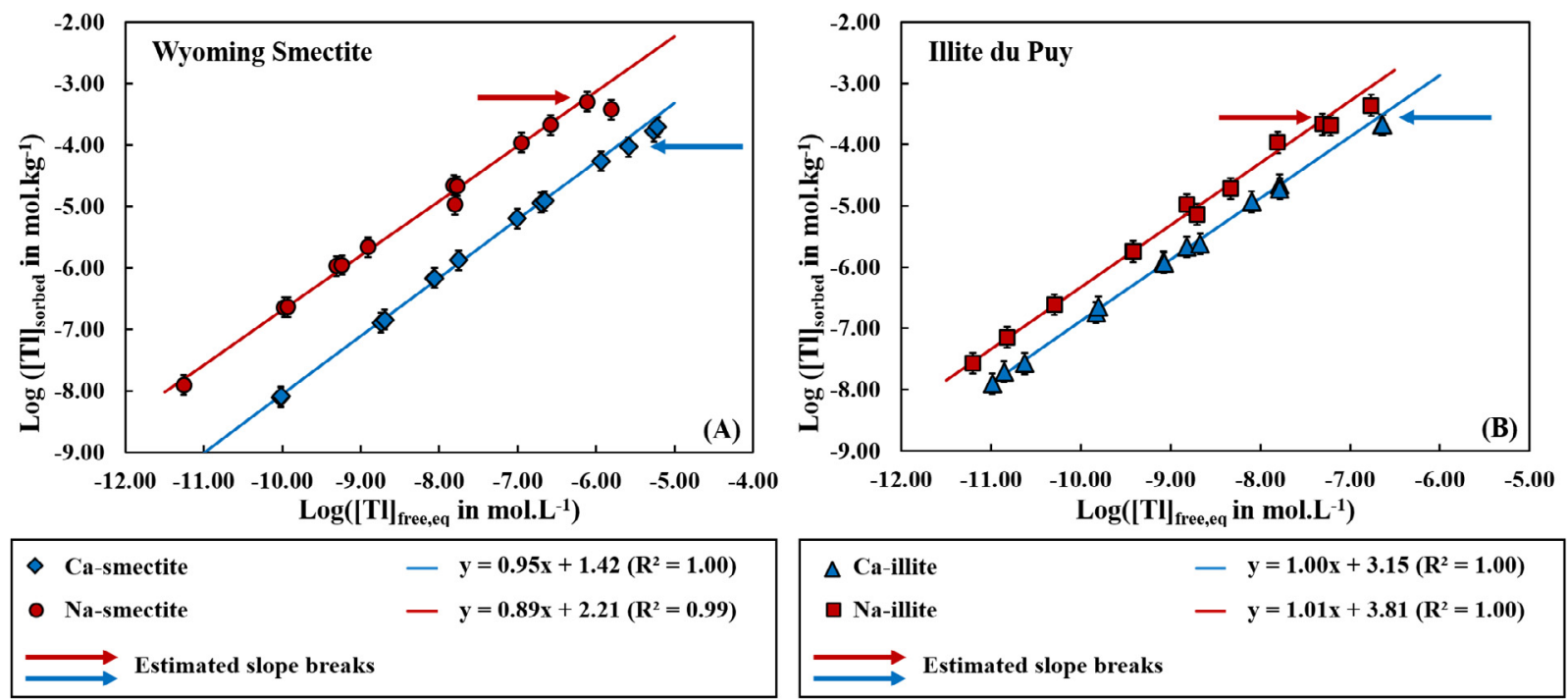

Fig. 2. Results in $\log [\mathrm{Tl}]_{\text {sorbed }}=\mathrm{f}\left([\mathrm{Tl}]_{\text {free,eq }}\right)$ for smectite (A) and illite (B). Error bars correspond to the variability of $\mathrm{Tl}$ sorbed. $\mathrm{pH}$ condition are $7.34 \pm 0.40,7.89 \pm 0.20,5.00 \pm 0.10$ and $7.18 \pm 0.08$ for respectively Na-smectite, Ca-smectite, Na-illite and Ca-illite (Figs. 3B, 4B, 5B and $6 \mathrm{~B}$ captions).

trace cations (Wissocq et al., in press; Missana et al., 2014a), here thallium, at $\log [\mathrm{Tl}]_{\mathrm{eq}}$ around $-7 \mathrm{Log}$ unit for Na-illite and Na-smectite.

Considering selectivity coefficient $\left(\mathrm{K}^{* \mathrm{i}}\right)$ values, the $\mathrm{X}_{0}$ or $\mathrm{X}_{\mathrm{s}}$ sites show the most affinity for Tl (Table 1). For the two studied clays, the sites selectivity can be ordered as, $\mathrm{X}_{0}>$ $\mathrm{X}_{1}>\mathrm{X}_{2}>\mathrm{X}_{3}$ (Table 1) for illite and as $\mathrm{X}_{\mathrm{s}}>\mathrm{X}_{\mathrm{a}}>\mathrm{X}_{\mathrm{b}}>\mathrm{X}_{\mathrm{c}}$ for smectite (Table 1). However the main difference between illite and smectite affinity for thallium comes from $\mathrm{K}^{* \mathrm{i}}$ values for $X_{0}$ and $X_{s}$. Values are respectively $10^{-3.87}$ for the first and $10^{-2.31}$ for the last (Table 1) when reported to protons. When reported to electrolyte cations, thallium affinity for low capacity and high reactivity sites $\left(\mathrm{X}_{0}\right.$ and $\left.\mathrm{X}_{\mathrm{s}}\right)$ is also higher than any other sites except for $\mathrm{X}_{\mathrm{c}}$ for Ca-smectite (Table 1). Nevertheless, thallium affinity for major sites remains higher than for sodium and calcium but lesser than for protons, which induces some $\mathrm{pH}$-dependence. As indicated by negative selectivity coefficient, illite and smectite have more affinity for thallium than for calcium, sodium (Table 1).

\subsection{Thallium adsorption as function of $\mathrm{pH}$}

In all cases, $\mathrm{Tl}$ adsorption is $\mathrm{pH}$ dependent. $\log K_{\mathrm{d}}$ increase from acidic $\mathrm{pH}$ to basic $\mathrm{pH}$ (Figs. 3A, 4A, 5A and $6 \mathrm{~A})$. This highlights the competition with protons for sorption sites, according to the electrolyte $(\mathrm{Na}$ or $\mathrm{Ca}$ ) remaining at constant concentration in the system and the progressive exchange with thallium on sorption sites. Besides, two kinds of behavior are identified, depending on the background cation. When the electrolyte is $\mathrm{Na}^{+}$, whatever clay mineral is in suspension, the $\mathrm{pH}$ effect on $\mathrm{Tl}$ uptake is significant below $\mathrm{pH}$ 6.0. Indeed, the largest variations of $K_{\mathrm{d}}$ with $\mathrm{pH}$ are observed with increasing $\mathrm{pH}$, whereas at $\mathrm{pH}$ over 6.0 , a plateau with roughly constant $\log K_{\mathrm{d}}$ is reached (Figs. 3A and 5A). Corresponding maximal $\log K_{\mathrm{d}}$ values are $\sim 3.16 \pm 0.16 \log \left(\mathrm{L} \mathrm{kg}^{-1}\right)$ for smectite and $\sim 4.00 \pm 0.17 \log \left(\mathrm{L} \mathrm{kg}^{-1}\right)$ for illite. In Nasmectite (Fig. 3A), from pH 3.5 to $6.0, \log K_{\mathrm{d}}\left(K_{\mathrm{d}}\right.$ in $\mathrm{L}$ $\left.\mathrm{kg}^{-1}\right)$ are between 2.51 and $3.10( \pm 0.16)$. For Na-illite below $\mathrm{pH} 6.0, \log K_{\mathrm{d}}$ range between $1.89 \pm 0.17$ and 4.00 \pm 0.17 . In contrast, when $\mathrm{Ca}^{2+}$ is the background cation, $K_{\mathrm{d}}$ evolution is gradual over the range of investigated $\mathrm{pH}$ (Figs. 4A and 6A). Except at low pH $(<4.0)$, the amount of thallium adsorbed onto clay minerals is more important on Na-illite, then on $\mathrm{Na}$-smectite and $\mathrm{Ca}$-illite almost in the same ranges. Ca-smectite holds the smallest amount of sorbed thallium.

The four sites considered in the model allow correct fitting of the smectite experimental data, both with $\mathrm{Na}^{+}$and $\mathrm{Ca}^{2+}$ (Figs. 3 And 4). Individual site contributions show that the high reactive site $\left(\mathrm{X}_{\mathrm{s}}\right)$ is this one which uptakes the most thallium by smectite in all $\mathrm{pH}$ conditions (Figs. 3A and 4A). They follow the same profile as experimental data with increasing $\log K_{\mathrm{d}}$ values before reaching a plateau for $\mathrm{pH}>5.0$. $\mathrm{X}_{\mathrm{a}}$ and $\mathrm{X}_{\mathrm{b}}$ also play a significant role in Tl uptake but only the $\log K_{\mathrm{d}}$ for $\mathrm{X}_{\mathrm{b}}$ site varies at low $\mathrm{pH}$ and remains constant above $\mathrm{pH} 5.0$ (Figs. 3A and 4A). The $\mathrm{X}_{\mathrm{a}}$ site displays a steady $\log K_{\mathrm{d}}$ along the range of tested $\mathrm{pH}$ (Figs. 3A and 4A). $\mathrm{X}_{\mathrm{c}}$ becomes more important at higher $\mathrm{pH}$ and its role increases with increasing $\mathrm{pH}$. In Nasmectite, it is significant from $\mathrm{pH} \sim 8.0$ and at $\mathrm{pH} 10.0$ and then occupies the second site contribution, express in term of $\log K_{\mathrm{d}}$ values, after $\mathrm{X}_{\mathrm{s}}$ site (Fig. 3A). Observations are similar for Ca-smectite but the $\mathrm{X}_{\mathrm{c}}$ site appears at $\mathrm{pH}$ 7.0 and equal the $\mathrm{X}_{\mathrm{s}}$ site in term of $\log K_{\mathrm{d}}$ from $\mathrm{pH} 10.0$ (Fig. 3A). In Fig. 4A, two experimental points at $\mathrm{pH}$ over 10.0 are well above the general trend $(\log K d \sim 2.50 \log$ $\left.\left(\mathrm{L} \mathrm{kg}^{-1}\right)\right)$ and were not considered in the study. It seems that calcite precipitations occurred in batches during $\mathrm{pH}$ adjustment with $\mathrm{Ca}(\mathrm{OH})_{2}$.

The combined contribution of all sites (red line, Figs. 5 and 6) describes effectively the experimental data. In Naillite, $\mathrm{Tl}$ sorption is driven by high reactive site $\mathrm{X}_{0}$ at $\mathrm{pH}$ less 

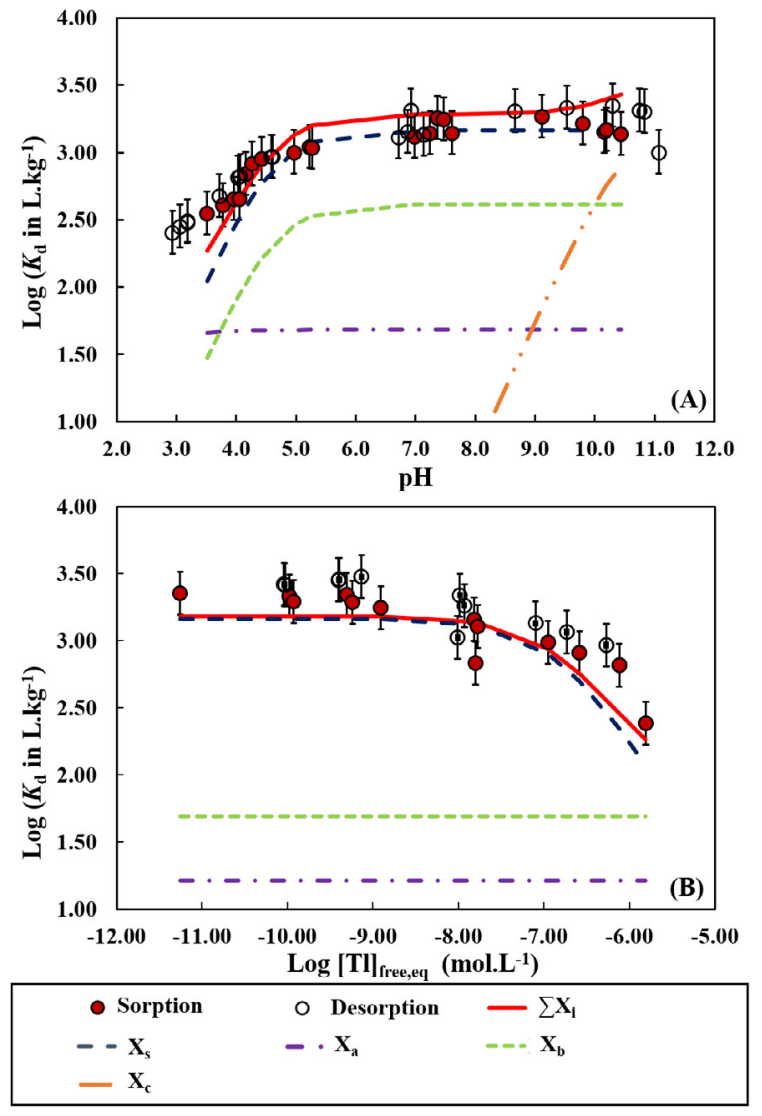

Fig. 3. Results for Na-smectite in $\log K_{\mathrm{d}}=\mathrm{f}(\mathrm{pH})$ (A) and in $\log K_{\mathrm{d}}$ $=\mathrm{f}\left([\mathrm{Tl}]_{\text {free }, \mathrm{eq}}\right)(\mathrm{B})$. In $\mathrm{A}$, introduced average $\mathrm{Tl}$ concentration is $[\mathrm{Tl}]_{\mathrm{t}=0}=2.24 \pm 0.08 \cdot 10^{-10} \mathrm{~mol} \mathrm{~L}^{-1}$. In $\mathrm{B}$, sorption average $\mathrm{pH}$ was $7.34 \pm 0.40$ and was $6.11 \pm 0.40$ during desorption. Dashed colorful lines correspond to the individual modeled reactive sites contributions. Red lines are the sum of each site contribution. Error bars correspond to the $K_{\mathrm{d}}$ variability. (For interpretation of the references to colour in this figure legend, the reader is referred to the web version of this article.)

than 3.0 (Fig. 5A). Then, a significant role is played by the $\mathrm{X}_{1}$ site, as it dominates $\mathrm{Tl}$ uptake for $\mathrm{pHs}$ between 4.0 and 7.0. A similar trend is observed for $\mathrm{X}_{2}$ (Fig. 5A) but from $\mathrm{pH}$ 4.0. It reaches $\mathrm{Tl}$ saturation around $\mathrm{pH} 8.0$ and uptakes as much thallium as the $\mathrm{X}_{1}$ site. From $\mathrm{pH}$ 8.0, $\mathrm{X}_{3}$ starts to uptake $\mathrm{Tl}$ but never reaches saturation under our conditions (Fig. 5A). The case of Ca-illite is different: $\mathrm{X}_{0}$ seems to uptake the majority of the thallium as it almost corresponds to the overall trend (Fig. 6A). Despite $\operatorname{low} \log K_{\mathrm{d}}$ $\left(<1.50 \log \left(\mathrm{L} \mathrm{kg}^{-1}\right)\right)$ the uptakes by sites $\mathrm{X}_{1}$ and $\mathrm{X}_{2}$ remain significant considering their exchange capacities (Fig. 6A). No role from the $X_{3}$ site is observed here (Fig. 6).

\subsection{Thallium adsorption as function of $\mathrm{Tl}$ concentrations}

In this section, partitioning coefficients are expressed in function of thallium concentrations measured at sorption equilibrium in the supernatant at fixed $\mathrm{pH} . \log K_{\mathrm{d}}$ values for comparable $\mathrm{pH}$ and $\mathrm{Tl}$ concentrations are similar to those from $\mathrm{pH}$ isotherms in all experiments (Figs. 3-6). Observations are the same with modeling results and for
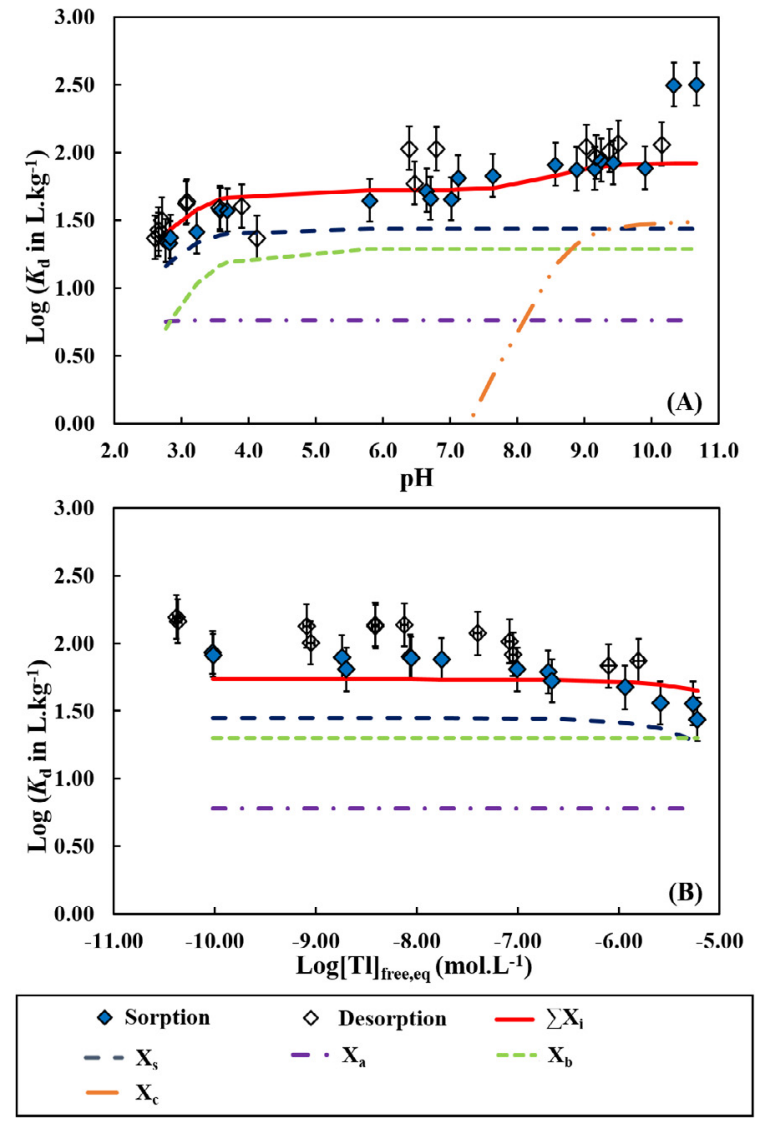

Fig. 4. Results for Ca-smectite in $\log K_{\mathrm{d}}=\mathrm{f}(\mathrm{pH})$ (A) and in $\log K_{\mathrm{d}}$ $=\mathrm{f}\left([\mathrm{Tl}]_{\text {free }, \mathrm{eq}}\right)$ (B). In A, introduced average $\mathrm{Tl}$ concentration, $[\mathrm{Tl}]_{\mathrm{t}=0}=2.12 \pm 0.29 \cdot 10^{-10} \mathrm{~mol} \mathrm{~L}^{-1}$. In $\mathrm{B}$, sorption average $\mathrm{pH}$ was $7.89 \pm 0.20$ and was $7.97 \pm 0.04$ during desorption. Dashed colorful lines correspond to contribution of individual modeled reactive sites. Red lines are the sum of each site contribution. Error bars correspond to the $K_{\mathrm{d}}$ variability. (For interpretation of the references to colour in this figure legend, the reader is referred to the web version of this article.)

all matrices, the highly reactive sites $\left(\mathrm{X}_{0}\right.$ or $\left.\mathrm{X}_{\mathrm{s}}\right)$ mainly contribute to uptake thallium at all concentrations (Figs. 4B, $5 \mathrm{~B}$ and $6 \mathrm{~B}$ ) except for Na-illite where $\mathrm{X}_{1}$ is dominant (Fig. 5B). $\log K_{\mathrm{d}}$ values remain constant until free thallium concentration reaches $10^{-8}$ (-8 in $\log$ scale) $\mathrm{mol} \mathrm{L}^{-1}$. Smooth declines in $\log K_{\mathrm{d}}$ are observed when $\mathrm{Ca}^{2+}$ is the background cation, from $10^{-8} \mathrm{~mol} \mathrm{~L}^{-1}$ and from $10^{-7}$ mol L ${ }^{-1}$ of free $\mathrm{Tl}$ for illite (Fig. 6B) and for smectite (Fig. 6A), respectively. No $\log K_{\mathrm{d}}$ decrease is seen on illite in sodic conditions (Fig. 5B) suggesting that sites saturation is not achieved under used concentrations. On the contrary, a clear break is evidenced for Na-smectite (Fig. 3B) implying that less thallium is adsorbed up to $10^{-8} \mathrm{~mol} \mathrm{~L}^{-1}$ of free cation.

\subsection{Adsorption reversibility}

From Figs. 3-6, both sorption and desorption data are presented. When thallium uptake by clay minerals is studied in function of $\mathrm{pH}$, the desorption $K d$ values are in the same range as sorption within error bars of each data set 

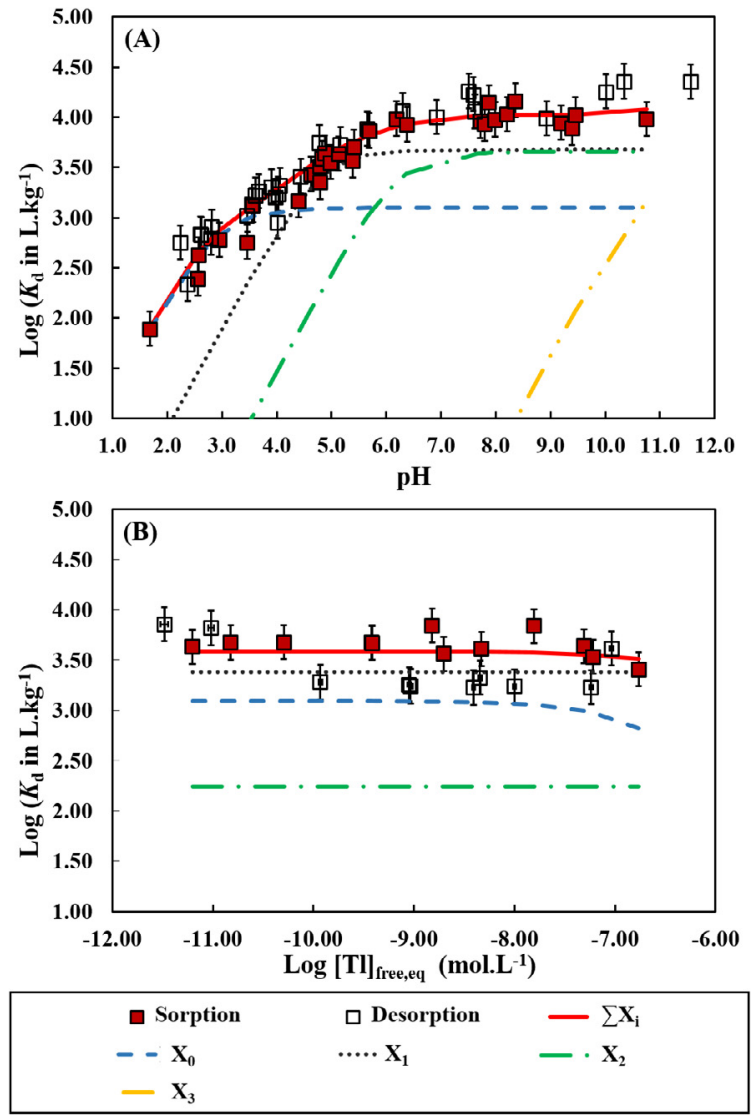

Fig. 5. Results for Na-illite in $\log K_{\mathrm{d}}=\mathrm{f}(\mathrm{pH})$ (A) and ion $\log K_{\mathrm{d}}=$ $\mathrm{f}\left([\mathrm{Tl}]_{\text {free }, \mathrm{eq}}\right)(\mathrm{B})$. In A, introduced average $\mathrm{Tl}$ concentration, $[\mathrm{Tl}]_{\mathrm{t}=0}$ $=4.01 \pm 0.95 \cdot 10^{-8} \mathrm{~mol} \mathrm{~L}^{-1}$. In $\mathrm{B}$, sorption average $\mathrm{pH}$ was 5.00 \pm 0.10 . For desorption, it was $5.00 \pm 0.46$ for points with $\log$ $[\mathrm{Tl}]_{\text {free,eq }}<-10 \mathrm{~mol} \mathrm{~L}^{-1}$ and for the point $(-7.03 ; 3.62)$. Then, it was $3.94 \pm 0.19$ for points with $\log [\mathrm{Tl}]_{\text {free eq }}>-10 \mathrm{~mol} \mathrm{~L}^{-1}$. Dashed colorful line correspond to contributions of individual modeled reactive sites. Red lines are the sum of each sites. Error bars correspond to the variability of the $K_{\mathrm{d}}$. (For interpretation of the references to colour in this figure legend, the reader is referred to the web version of this article.)

(Figs. 3A, 4A, 5A and 6A). Results are similar when thallium uptake is studied in function of $\mathrm{Tl}$ concentrations (Figs. 3B, 4B, 5B, 6B). Those results indicate that thallium sorption on clay minerals, both illite and smectite is reversible in all tested conditions.

Variability observed for desorption data in Fig. 5B is explained by different $\mathrm{pH}$ conditions within the set of batch experiments. The three values over $\log K_{\mathrm{d}}$ at $3.50 \log (\mathrm{L}$ $\mathrm{kg}^{-1}$ ) were acquired at $\mathrm{pH} 5.00 \pm 0.46$ while the other values $\left(\log K_{\mathrm{d}}<3.50 \log \left(\mathrm{L} \mathrm{kg}^{-1}\right)\right)$ where acquired at $\mathrm{pH} 3.94$ \pm 0.19 . When compared to the same $\mathrm{pH}$ conditions in Fig. $5 \mathrm{~A}$, the reversibility is attested.

\section{DISCUSSION}

This study represents the first description of thallium sorption with smectite. Hence, for this latter clay mineral, the set of selectivity coefficients obtained for thallium/pro-
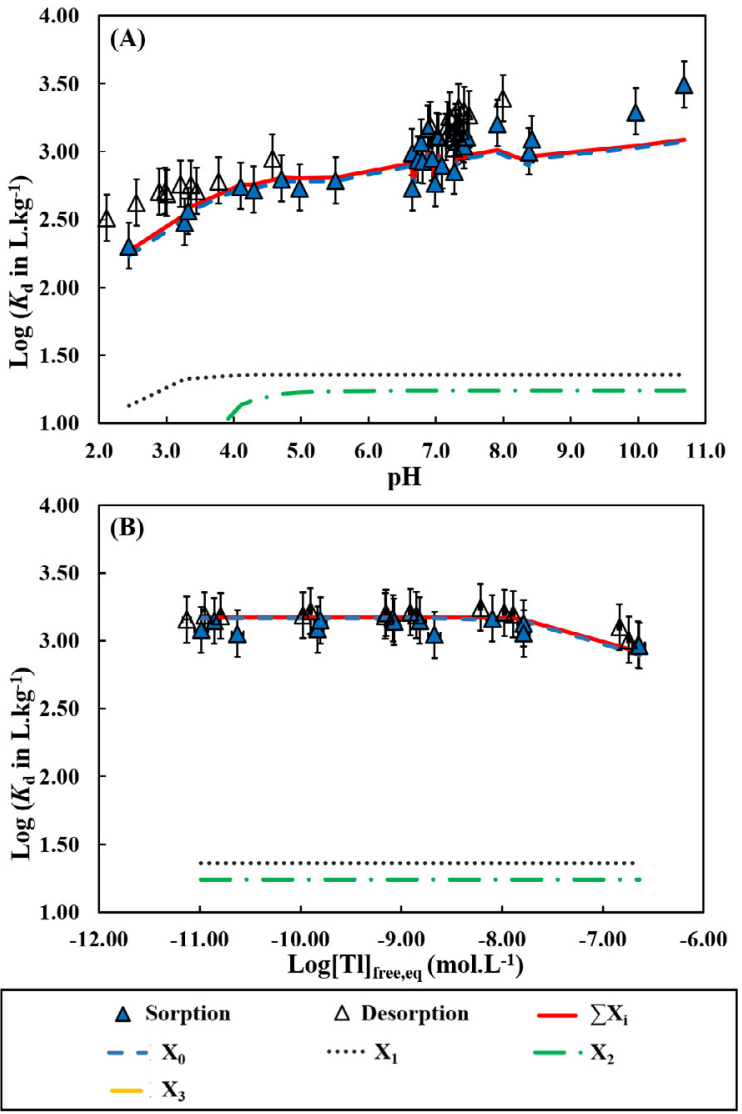

Fig. 6. Results for Ca-illite in $\log K_{\mathrm{d}}=\mathrm{f}(\mathrm{pH})(\mathrm{A})$ and in $\log K_{\mathrm{d}}=\mathrm{f}$ $\left([\mathrm{Tl}]_{\text {free,eq }}\right)(\mathrm{B})$. In $\mathrm{A}$, introduced average $\mathrm{Tl}$ concentration, $[\mathrm{Tl}]_{\mathrm{t}=0}$ $=4.37 \pm 0.18 \cdot 10^{-8} \mathrm{~mol} \mathrm{~L}^{-1}$. In $\mathrm{B}$, sorption average $\mathrm{pH}$ was 7.18 \pm 0.08 and was $7.14 \pm 0.19$ during desorption. Dashed colorful lines correspond to $\log K_{\mathrm{d}}$ for each modeled reactive sites. Red lines are the sum of each site contribution. Error bars correspond to the $K_{\mathrm{d}}$ variability. (For interpretation of the references to colour in this figure legend, the reader is referred to the web version of this article.)

tons exchange is also the first available up to our knowledge.

\subsection{Estimations of low capacity sites}

As mentioned previously, a low capacity site is evidenced at trace concentrations and is intrinsic to mineral properties (Baeyens and Bradbury, 1997; Poinssot et al., 1999; Tertre et al., 2009). Thus, no distinct site capacity value depending on physico-chemical conditions is expected as verified by low site capacity values that remain the same both in $\mathrm{Na}$ and $\mathrm{Ca}$ bulk solutions. Results with illite gave a value at $2.5 \cdot 10^{-4} \mathrm{eq} \mathrm{kg}^{-1}$ (Table 1) which is close to values obtained by Missana et al. (2014b) at $3.0 \cdot 10^{-4} \mathrm{eq} \mathrm{kg}^{-1}$ and by Poinssot et al. (1999) at $5.5 \cdot 10^{-4} \mathrm{eq} \mathrm{kg}^{-1}$ with Cs. On the other hand, they were estimated at $5.0 \cdot 10^{-3} \mathrm{eq} \mathrm{kg}^{-1}$ by Wissocq et al. (2017) with $\mathrm{Sr}$ sorption experiments and at $2.0 \cdot 10^{-3} \mathrm{eq} \mathrm{kg}^{-1}$ for $\mathrm{Zn}$ experiments (Altmann et al., 2015). For smectite, Baeyens and Bradbury (1997) calculated its capacity at $2.0 \cdot 10^{-3} \mathrm{eq} \mathrm{kg}^{-1}$ ( $\mathrm{Zn}$ experiments) 
whereas it was evaluated at $1.2 \cdot 10^{-4} \mathrm{eq}^{-1}$ by Missana et al. $(2014 \mathrm{a}, 2014 \mathrm{~b}), 1.0 \cdot 10^{-4} \mathrm{eq} \mathrm{kg}^{-1}$ by Wissocq et al. (in press) and finally at $5.0 \cdot 10^{-4} \mathrm{eq} \mathrm{kg}^{-1}$ by Peynet (2003), each issued from Cs sorption experiments. Values from this study are in the same range as those from literature. However, it appears that estimations calculated during sorption experiments with divalent cations give values roughly one order of magnitude higher than with monovalent ones.

Interpretations from multi-site ion exchanger theory allow only macroscopic descriptions of the sorption without any structural assignment. Compilation of the extensive literature on Cs adsorption by illite reported by Lammers et al. (2017) pointed out the importance of the high affinity site of illite for cesium fate and denoted its unclear structural origin. Many studies assume that these low capacity and high affinity sites, so called frayed edge sites (FES), occur in the clay particle edge and result from weathering process on illite (Poinssot et al., 1999) and smectite (Missana et al., 2014a). Their exchange capacities were estimated at $0.25 \%$ of clay CEC (Bradbury and Baeyens, 2000). Exchange capacity of $\mathrm{X}_{0}$ and $\mathrm{X}_{\mathrm{s}}$ determined on experimental data, represent respectively $0.1 \%$ and $0.02 \%$ of illite and smectite CEC. In term of chemical reactivity, the $\mathrm{X}_{0}$ and $\mathrm{X}_{\mathrm{s}}$ sites appear comparable to the high affinity sites ascribed to FES.

\subsection{Thallium sorption behavior towards clay minerals comparing with other cations}

\subsubsection{Thallium sorption behavior}

Thallium sorption behavior can be described by combining two main factors, affinity for the minerals and competition with a major element (here $\mathrm{Ca}^{2+}$ and $\mathrm{Na}^{+}$) for sorption sites. $\mathrm{Tl}$ affinity for each minerals is expressed by sorbed $\mathrm{Tl}$ (in $\mathrm{mol} \mathrm{kg}^{-1}$ ) normalized by sample CEC (in eq kg${ }^{-1}$ ). It appears that $\mathrm{Tl}$ affinity for illite is one order of magnitude higher than for smectite for both $\mathrm{Ca}^{2+}$ and $\mathrm{Na}^{+}$matrices (Table 2). However, experimental data clearly show that thallium uptake by smectite can equal thallium uptake by illite depending on the background cation (Figs. 3 and 6). Similarly, based on thallium affinity for the mineral and vice versa (Table 2), illite in $\mathrm{CaCl}_{2}$ should uptake as much thallium as illite in $\mathrm{NaCl}$ but it does not (Figs. 5 and 6). In the latest case, thallium and sodium exchange easily because they are both monovalent and only one $\mathrm{Tl}^{+}$is needed to exchange with one $\mathrm{Na}^{+}$. In contrast, in a $\mathrm{CaCl}_{2}$ solution, two $\mathrm{Tl}^{+}$are necessary to replace one $\mathrm{Ca}^{2+}$ and consequently, thallium uptake is limited. This phenomenon is also highlight in Na-smectite experiments (Fig. 3) where almost the same amount is taken up compared to an illite in $\mathrm{CaCl}_{2}$ (Fig. 6).

Table 2

Thallium affinity in moles of sorbed element normalized by sample CEC for illite and smectite at $\mathrm{pH}=7.0$.

\begin{tabular}{lll}
\hline Background cation & Illite & Smectite \\
\hline $\mathrm{Na}^{+}$ & $2.09 \cdot 10^{-7}$ & $5.65 \cdot 10^{-8}$ \\
$\mathrm{Ca}^{2+}$ & $2.03 \cdot 10^{-7}$ & $2.60 \cdot 10^{-8}$ \\
\hline
\end{tabular}

Competition between a trace and a major cation is somehow the greatest limiting factor in thallium uptake by clay minerals. Depending on $\mathrm{pH}$, thallium is first adsorbed onto $\mathrm{X}_{0}$ and $\mathrm{X}_{\mathrm{s}}$ sites, while they represent respectively $0.1 \%$ and $0.02 \%$ of illite and smectite CEC (Table 1 and Figs. 3-6), those sites dominate thallium uptake by clay minerals. Then, when $\mathrm{X}_{0}$ and $\mathrm{X}_{\mathrm{s}}$ are saturated, major sites control $\mathrm{Tl}$ sorption depending of their protonation state (Figs. 3A-6A). Nevertheless, competition for those sites is higher and the intrinsic properties of the major cation in solution get important. With sodium, exchange is easier and the site's affinity is less overtaken by the competitive effect, so major sites uptake more thallium. However, with calcium, exchange is more difficult and the competitive effect with other cation is greater than site's affinity for thallium. Consequently, thallium uptake is limited. This dual effect (competition vs. affinity) also explains why thallium uptake by $\mathrm{Ca}$-smectite is dominated by major sites at high $\mathrm{pH}(>7)$. Indeed, thallium has higher affinity for $X_{c}$ $\left(\mathrm{K}_{2 \mathrm{Tl}^{+} / \mathrm{Ca}^{2+}}^{\mathrm{i} *} 10^{-8.19}\right.$, Table 1) sites than calcium and so more $\mathrm{Tl}$ is taken up. As reported in rivers waters (Nielsen et al., 2005) and in anthropogenic contaminated area (Casiot et al., 2011), thallium concentration is below $10^{-6}$ mol L $\mathrm{L}^{-1}$. In our experimental conditions, $\mathrm{Tl}$ remains in trace concentrations $\left([\mathrm{Tl}]_{\mathrm{eq}}<10^{-6} \mathrm{M}\right)$ compared to the electrolyte cations. Consequently, $\mathrm{Tl}$ concentration is insufficient to saturate solely the clay CEC and Tl enters strongly in competition with major cations in solution. We can expect that the ionic strength of the background solution could influence the amount of adsorbed thallium as observed for other trace elements (Missana et al., 2014a, 2014b; Altmann et al., 2015). Then, thallium uptake would decrease with higher ionic strength.

In various environments, thallium is assumed to substitute potassium in secondary minerals (e.g. Nielsen et al., 2006, 2017; Prytulak et al., 2017). For instance, in illite, $\mathrm{K}^{+}$takes place as counter ion on the negative surface charges and is strongly bounded to the structure in the interlayer space (Meunier, 2003). Consequently, Tl integrated in the interlayer space during mineral formation may follow the same behavior as $\mathrm{K}$ in the environment and should be difficult to remove in the environmental physico-chemical conditions. In this study, no $\mathrm{K}$ was extracted by cationic exchange with Cs $(0.1 \mathrm{M})$ in order to quantify the exchangeable cations on the homo-ionic conditioned clay minerals. $\mathrm{K}$ stays strongly bounded in the illite interlayer space. However, original $\mathrm{Tl}$ is released from pre-conditioned homo-ionic illite and smectite, placed in $10^{-2} \mathrm{M} \mathrm{CaCl}_{2}$ and $\mathrm{NaCl}$ solutions at $\mathrm{pH} 7$ after 6 days (blanks tests, Section 2.3). This $\mathrm{Tl}$ release indicates that original $\mathrm{Tl}$ is exchangeable, contrary to $\mathrm{K}$. This residual and original $\mathrm{Tl}$ was not removed by the pre-conditioning step, suggesting its location was the interlayer space, as $\mathrm{K}$. However, this $\mathrm{Tl}$ seems time dependent to diffuse out from the interlayer space, whereas $\mathrm{K}$ stays bound inside. Fuller et al. (2015), Comans and Hockley (1992) suggested that $\mathrm{K} / \mathrm{Cs}$ exchange in the interlayer space result to an irreversible sorption process due to an interlayer collapse of weathered illites (Fuller et al., 2015) and a slow kinetic process. In our case, no collapse and saturation of the low 
capacity and high selectivity sites (assimilated to frayed edge sites- FES- in the literature) by only $\mathrm{Tl}$ are achieved at highest $\mathrm{Tl}$ concentration carried out at $\mathrm{pH} \sim 7$. In this later condition, the $2.5 \cdot 10^{-6}$ mole of introduced $\mathrm{Tl}$ may compensate the $2.5 \cdot 10^{-6}$ mole of available $\mathrm{X}_{0}$ or $\mathrm{X}_{\mathrm{s}}$ sites. However, only $8.7 \cdot 10^{-8}$ mole of $\mathrm{Tl}$ is adsorbed, suggesting that other cations $\left(\mathrm{Ca}^{2+}\right.$ or $\mathrm{Na}^{+}$and $\left.\mathrm{H}^{+}\right)$are involved to reach the complete $\mathrm{X}_{0}$ or $\mathrm{X}_{\mathrm{s}}$ saturation. Moreover, all experimental conditions verify the sorption reversibility. Consequently, $\mathrm{Tl}^{+}$remains removable from sorption sites and specifically from the low capacity and high selectivity sites.

Bradbury and Baeyens (2000) and Missana et al. (2014b) evidenced a strong depletion of $\mathrm{Cs}$ sorption on $\mathrm{K}$ - and $\mathrm{NH}_{4}$-illite. The strongest competition between $\mathrm{Cs}$ and $\mathrm{K}$ and $\mathrm{NH}_{4}$ mainly occurs at low Cs concentration and consequently concerns the low capacity and high selectivity sites. $\log K_{\mathrm{d}}$ of $\mathrm{Cs}$ on $\mathrm{K}$ - and $\mathrm{NH}_{4}$-illite remains almost steady ( $\log K_{\mathrm{d}}=2 \log$ unit) between $10^{-9}$ and $10^{-4} \mathrm{~mol} \mathrm{~L}^{-1} \mathrm{Cs}$ concentration at equilibrium $\left(\mathrm{I}=0.1 \mathrm{~mol} \mathrm{~L}^{-1}\right)$. Affinities for $\mathrm{K}$ and $\mathrm{NH}_{4}$ on illite-FES are comparable (Bradbury and Baeyens, 2000). On the contrary, $\mathrm{K}$ affinity for illite is two hundred fifty time more than $\mathrm{Na}$. In our study, Tl affinity on $\mathrm{X}_{0}$ site is $10^{4.74}$ higher than $\mathrm{Na}$. Considering both modeling approaches, $\mathrm{Tl}$ affinity tends to be higher than $\mathrm{K}$ for low capacity and high selectivity sites on illite. In a recent study, Wick et al. (2018) compiled and acquired selectivity coefficient of $\mathrm{Tl}$ towards $\mathrm{K}, \mathrm{Ca}, \mathrm{Na}$ and $\mathrm{NH}_{4}$ on homo-ionic illite and confirm this trend.

Nevertheless, thallium and potassium share some similar behavior mostly due to close ionic radii (Shannon, 1976). Classically, in soil solution or river water, $\mathrm{K}^{+}$concentration is ten-fold smaller than $\mathrm{Ca}^{2+}$. Then, the competition for site would increase with $\mathrm{K}$ in solution and less thallium uptake is expected, as observed for cesium (Missana et al., 2014a).

\subsubsection{Comparison with other trace cations}

$\mathrm{Tl}(\mathrm{I})$ with its main dissolved species $\mathrm{Tl}^{+}$, has a ionic radii of $1.50 \AA$, close to Rb (1.52 $\AA$ ) and Cs $(1.67 \AA$ ) (Shannon, 1976). Consequently, its behavior is often compared to alkali metals (e.g. Prytulak et al., 2017). Over the three cations, $\mathrm{Tl}$ is the one less sorbed on illite independently of the background cations (Brouwer et al., 1983, Poinssot et al., 1999; Missana et al., 2014b). For instance, in similar conditions (trace concentrations and ionic strength at 0.01 $\mathrm{M}$ ), cesium onto Na-illite shows $\log K_{\mathrm{d}}$ varying between $\sim 4.5$ to $\sim 5.0 \mathrm{~L} \mathrm{~kg}^{-1}$ as a function of $\mathrm{pH}$ (Poinssot et al., 1999), one order of magnitude higher than thallium ones. Then, alkali metals sorption onto illite can be ranked as follow, $\mathrm{Cs}>\mathrm{Rb}>\mathrm{Tl}$. For smectite, observations are similar and cesium sorption is larger than thallium (Missana et al., 2014a; Wissocq et al., in press).

In the studied context, no chalcophile vs. lithophile behavior (McGoldrick et al., 1979; Prytulak et al., 2017) for $\mathrm{Tl}$ can be involved. Thallium behaves as expected for cations with large ionic radii ( $\mathrm{Rb}, \mathrm{Cs}$ and $\mathrm{K}$ ) and displays weaker sorption interactions with the studied clay minerals. Nonetheless, contrary to Cs (Comans and Hockley, 1992; Fuller et al., 2015), Tl sorption on illite and smectite remains reversible. Some study explained this irreversibility by a dehydration of $\mathrm{Cs}$ in the anhydrous interlayer of illite (Lee et al., 2017). Moreover, Cs sorption reversibility is dependent on contact time and concentration (De Koning and Comans, 2004). By comparison, Tl adsorbed on the low capacity and high affinity site may preserve its hydration state. Then, at trace concentration in solution, Tl behavior seems to be driven by cationic exchange without bounding in the interlayer space.

\subsubsection{Comparison to other bearing phases}

Thallium sorption onto illite and smectite was compared to other data from laboratory experiments using pure mineral phases in simple electrolyte (here $\mathrm{NaCl}$ ), extracted from Bidoglio et al. (1993), Liu et al. (2011) and Casiot et al. (2011). Figures are presented in SI (Figs. S4 and S5). Note that ionic strengths are different for some phases, so thallium uptake by illite and smectite is probably overestimated (around one order of magnitude; Missana et al., 2014a; Altmann et al., 2015) with respect to goethite, $\delta-\mathrm{MnO}_{2}, \gamma-$ $\mathrm{Al}_{2} \mathrm{O}_{3}$ and $\mathrm{SiO}_{2}$ (Bidoglio et al., 1993). Nevertheless, it appears that manganese (here $\delta-\mathrm{MnO}_{2}$ ) oxides adsorb the most $\mathrm{Tl}(\mathrm{I})$, whereas silica adsorbs less. Aluminum oxides could compete in controlling $\mathrm{Tl}$ in solution with both illite and smectite at alkaline $\mathrm{pH}(>10)$. Casiot et al., (2011) evidenced a weak thallium sorption to ferrihydrite that is similar to smectite (same ionic strength) at $\mathrm{pH}>7$ (SI Fig. S5). At near neutral (in natural waters conditions) and acidic $\mathrm{pH}$, thallium sorption is dominated first by manganese oxides and then by clay minerals. Bearing phases could be ranked as follow (order of decreasing sorption): $\delta-\mathrm{MnO}_{2}$ $>$ illite $>$ smectite $\sim$ ferrihydrite $\geq \gamma-\mathrm{Al}_{2} \mathrm{O}_{3} \sim$ goethite $>$ $\mathrm{SiO}_{2}$.

Few studies have addressed $\mathrm{Tl}(\mathrm{I})$ sorption processes, mostly on manganese oxides and iron oxihydroxides (Bidoglio et al., 1993; Lin and Nriagu, 1998; Casiot et al., 2011; Peacock and Moon, 2012; Coup and Swedlund, 2015) so far. Nevertheless, Peacock and Moon (2012) identified two types of interaction depending on the bearing phases. In presence of todorokite, triclinic birnessite and ferrihydrite, $\mathrm{Tl}(\mathrm{I})$ expressed as hydrated $\mathrm{Tl}^{+}$(outer sphere complexes), forms weak interactions with the reactive sites of those minerals (Peacock and Moon, 2012). It is likely due to $\mathrm{Tl}(\mathrm{I})$ shell electron configuration and its large ionic radii (Persson et al., 2002). On the contrary, when hexagonal birnessite is present, $\mathrm{Tl}(\mathrm{I})$ is oxidized in $\mathrm{Tl}(\mathrm{III})$, which is then strongly bound (inner sphere or tridentate complexes) at the vacant octahedral sites of the minerals (Peacock and Moon, 2012; Nielsen et al., 2013). This oxidation of thallium seems to occur only at low dissolved $\mathrm{Tl}$ concentrations (Nielsen et al., 2013) and is limited and replaced by $\mathrm{Tl}(\mathrm{I})$ adsorption at higher $\mathrm{Tl}$ concentration relevant in $\mathrm{Tl}$ polluted area (Nielsen et al., 2013).

In our experiments, observed adsorption reversibility evidences that thallium sorption onto clay minerals is driven by exchange reactions and consequently weak interactions. This might exclude thallium adsorption via $\mathrm{Tl}(\mathrm{I})$ oxidation in Tl(III) on reactive sites for instance. In conclusion, this confirm thallium displays weak binding to clay minerals, possibly due to simple exchange between 
hydrated cations but more data are necessary to perfectly understand all processes involved here.

\subsection{Implications for thallium mobility in the environment}

Comparing with natural multi-component samples, only few phases contribute strongly for controlling thallium solubility. For instance, up to our knowledge, no Tl adsorption onto aluminum oxides or even silica have been ever observed in natural samples.

Various studies identified thallium associated with manganese oxides and aluminosilicates as the main bearing phases for thallium in soils (Tremel et al., 1997; Jacobson et al., 2005a; Vaněk et al., 2009, 2011, 2013; Voegelin et al., 2015; Antic-Mladenovic et al., 2017). The present study confirms that illite is an important bearing phase for Tl. Moreover, it seems thallium goes preferentially on illite clays instead of smectite (Voegelin et al., 2015) which is in accordance with the lower $\mathrm{Tl}$ affinity evidenced in this study. However, in many studies where sequential extractions are used, thallium associated to aluminosilicates is always assimilated to the residual fractions without exchange capacity (Vaněk et al., 2009, 2013; GomezGonzalez et al., 2015). It is assumed that thallium is either in primary minerals such as micas or feldspar for instance (Vaněk et al., 2009; Gomez-Gonzalez et al., 2015) or substituted to $\mathrm{K}$ in illite interlayer space (Jacobson et al., 2005b; Vaněk et al., 2013; Voegelin et al., 2015). However, results from the present study does not confirm the latest assumption. Indeed, a total reversibility of the $\mathrm{Tl}$ sorption and a release of $\mathrm{Tl}$ originally present in clay (both illite and smectite) at $\mathrm{pH} 7$ show a high exchange capacity for Tl. Divergences between these results could be explain by both the thallium origin and the experimental methods used. In the present study, $\mathrm{Tl}$ is introduced as an anthropogenic contaminant whereas in soils studies, such as Voegelin et al., (2015), Tl is incorporated into illite inherited (or newly formed) from a Tl-rich bedrock during soil formation. Then it questioned $\mathrm{Tl}$ origin and geogenic processes responsible of its enrichment in the parent material. It is known that during hydrothermal alteration, thallium can be enriched in K-rich minerals (Baker et al., 2010). Due to their ionic radius, both $\mathrm{Tl}$ and $\mathrm{K}$ may be incorporated inside the crystal lattice. On the contrary, when thallium is introduced in free $\mathrm{Tl}^{+}$form in solution by anthropogenic activities, it accesses solely to the reactive surface charges of minerals.

The exchangeable interactions between thallium and clays suggest that in changing environmental conditions, thallium could be released from bearing phases. This process may contribute to the thallium bioavailability and could explain the limited contribution of illite on thallium trapping in several soils (Vaněk et al., 2011). In a Tl-rich soil, Tl uptake by illlite appears to be dominant over other pedogenic phases such as Mn-oxides for instance (Voegelin et al., 2015). The $\mathrm{Tl} / \mathrm{Mn}$ ratio is known to be determinant in $\mathrm{Tl}$ sorption onto manganese oxides. Tl excess saturates $\mathrm{Mn}$ oxide sorption sites, which constrains its retention effect in soils for instance (Peacock and Moon, 2012; Voegelin et al., 2015). Due to higher $\mathrm{Tl}$ affinity for $\mathrm{Mn}$ oxides, $\mathrm{Tl}$ is expected to be trapped preferentially by those minerals.
Then, clays and especially illite, could have an important role in controlling $\mathrm{Tl}$ uptake at high concentrations (i.e. polluted soils, sediments or in acid mine drainage). In these complex media, i.e. soil, the relative amounts of bearing phases have to be considered to estimate their contribution in the thallium fate.

The role of clay minerals in other environmental compartments is not clear due to lack of studies. In rivers, aqueous $\mathrm{Tl}(\mathrm{I})$ species are mainly dissolved and the thallium loaded in particulate matter seems limited (Law and Turner, 2011). Nevertheless, in lake and river sediments, we can assume that clay minerals are dominant bearing phases and can be responsible for thallium output fluxes from water column as in oceans (Rehkämper and Nielsen, 2004). In estuarine conditions where particles are small and often re-suspended, thallium seems mostly fixed on particles (Law and Turner, 2011). In this context, illite or smectite, given their quick exchange kinetics with thallium (roughly two days) could play an important role, especially in freshwater where $\mathrm{Tl}$ seems to mostly be sorbed on particles (Turner et al., 2010).

\section{SUMMARY AND CONCLUSIONS}

Illite du Puy and Wyoming smectite were used in this study to assess the sorption behavior of thallium as $\mathrm{Tl}(\mathrm{I})$ to clays. Batch experiments at a constant ionic strength of $0.01 \mathrm{~mol} \mathrm{~L}^{-1}$ with various $\mathrm{pH}$ and $\mathrm{Tl}$ concentration conditions were performed. $\mathrm{Na}^{+}$or $\mathrm{Ca}^{2+}$ were used as background cations for all experiments. Experimental results were interpreted with the help of a multi-site ion exchanger model. Our results showed that illite exhibits more affinity for thallium than smectite. In both cases, independently of the background electrolyte, $\mathrm{Tl}$ affinity for low capacity and highly reactive sites were dominant in thallium uptake. The exchange reversibility and weak interactions between $\mathrm{Tl}^{+}$and reactive clay sites suggested cation exchange as dominant mechanism.

The role of clay minerals in thallium environmental cycle is evident but more studies are needed to understand all the mechanism involved. On one hand, more descriptions of thallium interactions with clays in various environments such as lake, river and estuary sediments and particulate matter would be interesting. New environmental measurements will benefit from our database and modeling approach and Tl-clay interactions will be modeled to gain a better understanding of $\mathrm{Tl}$ behavior. A modeling approach considering additivity of the bearing phases sorption properties in natural media will be useful to simulate the thallium fate in diverse environments. In parallel, studies to evidence the sorption mechanisms are important especially concerning the type of bonding and the possible thallium migration in interlayers of clay minerals. Finally, thallium substitution of potassium is prevalent in geogenic processes and is present in weathering products of various K-bearing minerals. Thus, it would be interesting in the future to distinguish the source of thallium in illite, for instance, and to know whether it was already present in the parent mineral or thallium complex due to sub(surface) environmental processes. 
Tl(III) also has been observed in some aquatic environments (Campanella et al., 2017; Campanella et al., 2018) but no information about its interactions with clay minerals exists. It could be usefull to assess the potential role of those minerals in $\mathrm{Tl}$ (III) stability in natural waters for instance.

\section{ACKNOWLEDGEMENTS}

The authors thank IRSN, CEA, BRGM and IPGP for funding this research. Parts of this work were supported by IPGP multidisciplinary program PARI and by Region Ile de France SESAME Grant no. 12015908. Logan Rand is acknowledged for his helpful English proofreading.

\section{APPENDIX A. SUPPLEMENTARY MATERIAL}

Supplementary data associated with this article can be found, in the online version, at https://doi.org/10.1016/j. gca.2018.03.016.

\section{REFERENCES}

Altmann S., Aertsens M., Appelo T., Bruggeman C., Gaboreau S., Glaus M., Jacquier P., Kupcik T., Maes N., Montoya V. et al. (2015). Processes of cation migration in clayrocks. Final Scientic Report of the CatClay European Project. 140p.

Antic-Mladenovic S., Frohne T., Kresovic M., Stärk H.-J., Savic D., Ličina V. and Rinklebe J. (2017) Redox-controlled release dynamics of thallium in periodically flooded arable soil. Chemosphere 178, 268-276.

Baeyens B. and Bradbury M. H. (1997) A mechanistic description of $\mathrm{Ni}$ and $\mathrm{Zn}$ sorption on Part I: Titration and sorption measurements. J. Contam. Hydrol. 27, 199-222.

Baker R. G. A., Rehkämper M., Ihlenfeld C., Oates C. J. and Coggon R. (2010) Thallium isotope variations in an ore-bearing continental igneous setting: Collahuasi formation, northern Chile. Geochim. Cosmochim. Acta 74, 4405-4416.

Bennett S. M. (2017) Thallium. In Mineral Commodity Summaries. US Geological Survey, pp. 170-171.

Biagioni C., D’Orazio M., Vezzoni S., Dini A. and Orlandi P. (2013) Mobilization of TI-Hg-As-Sb-(Ag, Cu)-Pb sulfosalt melts during low-grade metamorphism in the Alpi Apuane (Tuscany, Italy). Geology 41, 747-750.

Bidoglio G., Gibson P. N., O’Gorman M. and Roberts K. J. (1993) $\mathrm{X}$-ray absorption spectroscopy investigation of surface redox transformations of thallium and chromium on colloidal mineral oxides. Geochim. (Beijing) Cosmochim. Acta 57, 2389-2394.

Bradbury M. H. and Baeyens B. (2000) A generalized sorption model for the concentration dependent uptake of caesium by argillaceous rocks. J. Contam. Hydrol. 42, 141-163.

Bradbury M. H. and Baeyens B. (2002) Sorption of Eu on Na- and Ca-montmorillonites: Experimental investigations and modelling with cation exchange and surface complexation. Geochim. Cosmochim. Acta 66, 2325-2334.

Brouwer E., Baeyens B., Maes A. and Cremers A. (1983) Cesium and rubidium ion equilibriums in illite clay. J. Phys. Chem. 87, $1213-1219$

Campanella B., Casiot C., Onor M., Perotti M., Petrini R. and Bramanti E. (2017) Talanta Thallium release from acid mine drainages: speciation in river and tap water from Valdicastello mining district (northwest Tuscany). Talanta 171, 255-261.
Campanella B., D’Ulivo A., Ghezzi L., Onor M., Petrini R. and Bramanti E. (2018) Influence of environmental and anthropogenic parameters on thallium oxidation state in natural waters. Chemosphere 196, 1-8.

Casiot C., Egal M., Bruneel O., Verma N., Parmentier M. and Elbaz-Poulichet F. (2011) Predominance of aqueous Tl(I) species in the river system downstream from the abandoned Carnoulès Mine (Southern France). Environ. Sci. Technol. 45, 2056-2064.

Cheam V. (2001) Thallium contamination of water in Canada. Water Qual. Res. J. Canada 36, 851-877.

Comans R. N. J. and Hockley D. E. (1992) Kinetics of cesium sorption on illite. Geochim. (Beijing) Cosmochim. Acta 56, $1157-1164$.

Coup K. M. and Swedlund P. J. (2015) Demystifying the interfacial aquatic geochemistry of thallium(I): new and old data reveal just a regular cation. Chem. Geol. 398, 97-103.

De Koning A. and Comans R. N. J. (2004) Reversibility of radiocaesium sorption on illite. Geochim. (Beijing) Cosmochim. Acta 68, 2815-2823. https://doi.org/10.1016/j.gca.2003.12.025.

Fuller A. J., Shaw S., Ward M. B., Haigh S. J., Mosselmans J. F., Peacock C. L., Stackhouse S., Dent A. J., Trivedi D. and Burke I. T. (2015) Caesium incorporation and retention in illite interlayers. Appl. Clay Sci. 108, 128-134.

Gabis V. (1958) Etude préliminaire des argiles oligocènes du Puyen-Velay (Haute-Loire). Bull. Soc. Franç. Minéral. Cristallog. 81, 183-185.

Gomez-Gonzalez M. A., Garcia-Guinea J., Laborda F. and Garrido F. (2015) Thallium occurrence and partitioning in soils and sediments affected by mining activities in Madrid province (Spain). Sci. Total Environ. 536, 268-278.

Gorgeon L. (1994) Contribution à la modélisation physico-chimique de la rétention de radioéléments à vie longue par des matériaux argileux. PhD. thesis. Univ. Paris 06.

Guillaume D. (2002) Etude expérimentale du système fer-smectite en solution à 80 et $300^{\circ} \mathrm{C}$. Ph. D. thesis, Univ. Henri Poincaré, Nancy.

Hettmann K., Marks M. A. W., Kreissig K., Zack T., Wenzel T., Rehkämper M., Jacob D. E. and Markl G. (2014) The geochemistry of $\mathrm{Tl}$ and its isotope during magmatic and hydrothermal processes: the peralkaline Ilimaussaq complex, southwest Greenland. Chem. Geol. 366, 1-13.

Jacobson A. R., McBride M. B., Baveye P. and Steenhuis T. S. (2005a) Environmental factors determining the trace-level sorption of silver and thallium to soils. Sci. Total Environ. 345, 191-205.

Jacobson A. R., Klitzke S., McBride M. B., Baveye P. and Steenhuis T. S. (2005b) The desorption of silver and thallium from soils in the presence of chelating resin with thiol functional groups. Water, Air, Soil Pollut. 160, 41-54.

Jacquier P., Ly J. and Beaucaire C. (2004) The ion-exchange properties of the Tournemire argillite. study of the $\mathrm{H}, \mathrm{Na}, \mathrm{K}$, Cs, Ca and Mg behaviour. Appl. Clay Sci. 26, 163-170.

Kaplan D. I. and Mattigod S. V. (1998) Aqueous geochemistry of thallium. In Thallium in the Environment (ed. J. O. Nriagu). John Wiley \& Sons Inc., New York, pp. 15-30.

Karbowska B. (2016) Presence of thallium in the environment: sources of contaminations, distribution and monitoring methods. Environ. Monit. Assess. 164, 640-658.

Karlsson U., Karlsson S. and Düker A. (2006) The effect of light and iron(II)/iron(III) on the distribution of Tl(i)/Tl(iii) in fresh water systems. J. Environ. Monit. 8, 634-640.

Karnland O. (2010) Chemical and mineralogical characterization of the bentonite buffer for the acceptance control procedure in a KBS-3 repository (No. SKB-TR-10-60). Swedish Nuclear Fuel 
and Waste Management Co. <http://www.iaea.org/inis/collection/NCLCollectionStore/_Public/43/003/43003619.pdf>.

Lammers L. N., Bourg I. C., Okumura M., Kolluri K., Sposito G. and Machida M. (2017) Molecular dynamics simulations of cesium adsorption on illite nanoparticles. J. Colloid Interface Sci. 490, 608-620.

Law S. and Turner A. (2011) Thallium in the hydrosphere of south west England. Environ. Pollut. 159, 3484-3489.

Lee J., Park S.-M., Jeon E.-K. and Baek K. (2017) Selective and irreversible adsorption mechanism of cesium on illite. Appl. Geochem. 83, 188-193.

Lin T.-S. and Nriagu J. (1998) Speciation of thallium in natural waters. In Thallium in the Environment (ed. J. O. Nriagu). John Wiley \& Sons Inc., New York, pp. 31-44.

Lin T.-S. and Nriagu J. (1999) Thallium speciation in the great Lakes. Environ. Sci. Technol. 33, 3394-3397.

Lis J., Pasieczna A., Karbowska B., Zembrzuski W. and Lukaszewski Z. (2003) Thallium in soils and stream sediments of a $\mathrm{Zn}-\mathrm{Pb}$ mining and smelting area. Environ. Sci. Technol. 37, 4569-4572.

Liu J., Lippold H., Wang J., Lippmann-Pipke J. and Chen Y. (2011) Sorption of thallium(I) onto geological materials: influence of $\mathrm{pH}$ and humic matter. Chemosphere 82, 866-871.

Maes A., Verheyden D. and Cremers A. (1985) Formation of highly selective cesium-exchange sites in montmorillonites. Clays Clay Minerals 33, 251-257.

McGoldrick P. J., Keays R. R. and Scott B. B. (1979) Thallium: a sensitive indicator of rock/seawater interaction and of sulfur saturation of silicate melts. Geochim. (Beijing) Cosmochim. Acta 43, 1303-1311.

Meunier A. (2003) Argiles. Collection Géosciences, Editions Scientifiques GB-SGF, Paris.

Missana T., Benedicto A., Garcia-Gutiérrez M. and Alonso U. (2014a) Modeling cesium retention onto Na-, K- and Casmectite: effects of ionic strength, exchange and competing cations on the determination of selectivity coefficients. Geochim. Cosmochim. Acta 128, 266-277.

Missana T., Garcia-Gutiérrez M. and Alonso U. (2014b) Modelling of Cs sorption in natural mixed-clays and the effects of ion competition. Appl. Geochem. 49, 95-102.

Motellier S., Ly J., Gorgeon L., Charles Y., Hainos D., Meier P. and Page J. (2003) Modelling of the ion-exchange properties and indirect determination of the interstitial water composition of an argillaceous rock. Application to the Callovo-Oxfordian low-water-content formation. Appl. Geochem. 18, 1517-1530.

Nielsen S. G., Rehkämper M., Porcelli D., Andersson P., Halliday A. N., Swarzenski P. W., Latkoczy C. and Günther D. (2005) Thallium isotope composition of the upper continental crust and rivers - an investigation of the continental sources of dissolved marine thallium. Geochim. Cosmochim. Acta 69 , 2007-2019.

Nielsen S. G., Rehkämper M., Teagle D. A. H., Butterfield D. A., Alt J. C. and Halliday A. N. (2006) Hydrothermal fluid fluxes calculated from the isotopic mass balance of thallium in the ocean crust. Earth Planet. Sci. Lett. 251, 120-133.

Nielsen S. G., Wasylenki L. E., Rehkämper M., Peacock C. L., Xue Z. and Moon E. M. (2013) Towards an understanding of thallium isotope fractionation during adsorption to manganese oxides. Geochim. (Beijing) Cosmochim. Acta 117, 252-265.

Nielsen S. G., Prytulak J., Blusztajn J., Yunchao S., Auro M., Regelous M. and Walker J. (2017) Thallium isotopes as tracers of recycled materials in subduction zones: Review and new data for lavas from Tonga-Kermadec and Central America. $J$. Volcanol. Geotherm. Res. 339, 23-40.
Nolin D. (1997) Rétention de radioéléments à vie longue par des matériaux argileux. Influence d'anions contenus dans les eaux naturelles. Ph. D. thesis. Univ. Paris 06.

Peacock C. L. and Moon E. M. (2012) Oxidative scavenging of thallium by birnessite: explanation for thallium enrichment and stable isotope fractionation in marine ferromanganese precipitates. Geochim. (Beijing) Cosmochim. Acta 84, 297-313.

Persson I., Jalilehvand F. and Sandström M. (2002) Structure of the solvated thallium(i) ion in aqueous, dimethyl sulfoxide, $N$, $N$-dimethylpropyleneurea, and $N, N$-dimethylthiolformanide solution. Inorg. Chem. 41, 192-197.

Peter A. L. J. and Viraraghavan T. (2005) Thallium: a review of public health and environmental concerns. Environ. Int. 31, 493-501.

Peynet V. (2003) Rétention d'actinide et de produits de fission par des phases solides polyminérales. Ph. D. thesis. Univ. Paris 06.

Poinssot C., Baeyens B. and Bradbury M. H. (1999) Experimental and modelling studies of caesium sorption on illite. Geochim. Cosmochim. Acta 63, 3217-3227.

Prytulak J., Brett A., Webb M., Plank T., Rehkämper M., Savage P. S. and Woodhead J. (2017) Thallium elemental behavior and stable isotope fractionation during magmatic processes. Chem. Geol. 448, 71-83.

Rehkämper M. and Nielsen S. G. (2004) The mass balance of dissolved thallium in the oceans. Marine Chem. 85, 125-139.

Reinoso-Maset E. and Ly J. (2014) Study of major ions sorption equilibria to characterize the ion exchange properties of kaolinite. J. Chem. Eng. Data 59, 4000-4009.

Rodríguez-Mercado J. J. and Altamirano-Lozano M. A. (2013) Genetic toxicology of thallium: a review. Drug Chem. Toxicol. 36, 369-383.

Savoye S., Beaucaire C., Fayette A., Herbette M. and Coelho D. (2012) Mobility of cesium through the callovo-oxfordian claystones under partially saturated conditions. Environ. Sci. Technol. 46, 2633-2641.

Shannon R. D. (1976) Revised effective ionic radii and systematic studies of interatomic distances in halides and chalcogenides. Acta Cryst. 32, 751-767.

Shaw D. M. (1952) The geochemistry of thallium. Geochim. (Beijing) Cosmochim. Acta 2, 118-154.

Tertre E., Beaucaire C., Coreau N. and Juery A. (2009) Modelling $\mathrm{Zn}$ (II) sorption onto clayey sediments using a multi-site ionexchange model. Appl. Geochem. 24, 1852-1861.

Tremel A., Masson P., Sterckeman T., Baize D. and Mench M. (1997) Thallium in French Agrosystems-I. Thallium contents in arable soils. Environ. Pollut. 95, 293-302.

Turner A., Cabon A., Glegg G. A. and Fisher A. S. (2010) Sediment-water interactions of thallium under simulated estuarine conditions. Geochim. (Beijing) Cosmochim. Acta 74, 6779-6787.

Vaněk A., Chrastný V., Mihaljevič M., Drahota P., Grygar T. and Komárek M. (2009) Lithogenic thallium behavior in soils with different land use. J. Geochem. Explor. 102, 7-12.

Vaněk A., Komárek M., Vokurková P., Mihaljevič M., Sebek O., Panuskova G., Chrastný V. and Drabek O. (2011) Effect of illite and birnessite on thallium retention and bioavailability in contaminated soils. J. Hazard. Mater. 191, 170-176.

Vaněk A., Chrastný V., Komárek M., Penížek V., Teper L., Cabala J. and Drábek O. (2013) Geochemical position of thallium in soils from a smelter-impacted area. J. Geochem. Explor. 124, 176-182.

Van Olphen H. and Fripiat J. J. (1979) Data Handbook for Clay Materials and Other Non-metallic Minerals: Providing those Involved in Clay Research and Industrial Application with Sets of Authoritative Data Describing the Physical and Chemical Prop- 
erties and Mineralogical Composition of the Available Reference Materials. Pergamon Press, Oxford.

Vink B. W. (1993) The behavior of thallium in the (sub) surface environment in terms of Eh and pH. Chem. Geol. 109, 119-123.

Voegelin A., Pfenninger N., Petrikis J., Majzlan J., Plötze M., Senn A.-C. and Göttlicher J. (2015) Thallium speciation and extractability in a thallium- and arsenic-rich soil developed from mineralized carbonate rock. Environ. Sci. Technol. 49, 5390-5398.

Wick S., Baeyens B., Marques Fernades M. and Voegelin A. (2018) Thallium Adsorption onto Illite. Environ. Sci. Technol. 52, 571580 .

Wissocq A., Beaucaire C. and Latrille C. (2017) Ca and Sr sorption on Ca-illite: experimental study and modelling. Proc. Earth Planet. Sci. 17, 662-665.

Wissocq A., Beaucaire C. and Latrille C. (in press) Application of the multi-site ion exchanger model to the sorption of $\mathrm{Sr}$ and $\mathrm{Cs}$ on a natural sandstone. Appl. Geochem. https://doi.org/ 10.1016/j.apgeochem.2017.12.010.

Xiao T., Guha J., Boyle D., Liu C. and Chen J. (2004) Environmental concerns related to high thallium levels in soils and thallium uptake by plants in southwest Guizhou, China. Sci. Total Environ. 318, 223-244.

Xiong Y. (2009) The aqueous geochemistry of thallium: speciation and solubility of thallium in low temperature systems. Environ. Chem. 6, 441-451.

Xiong Y. (2007) Hydrothermal thallium mineralization up to $300^{\circ}$ C: A thermodynamic approach. Ore Geology Reviews 32, 291313.

Associate editor: Mario Villalobos 